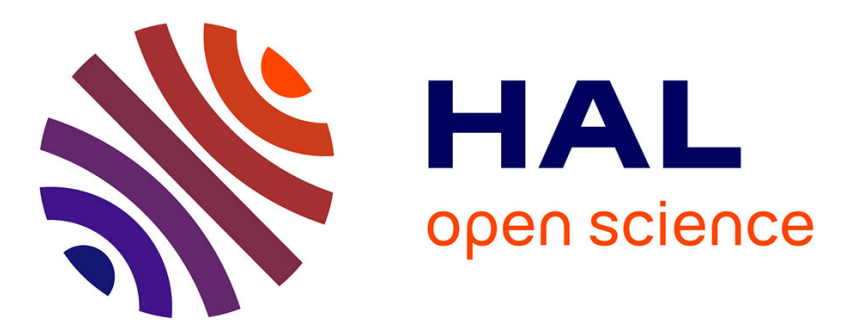

\title{
Trace metal limitations (Co, Zn) increase PIC/POC ratio in coccolithophore Emiliania huxleyi
}

\author{
Marie Boye, Mohamed Adjou, Gabriel Dulaquais, Paul Tréguer
}

\section{To cite this version:}

Marie Boye, Mohamed Adjou, Gabriel Dulaquais, Paul Tréguer. Trace metal limitations (Co, Zn) increase PIC/POC ratio in coccolithophore Emiliania huxleyi. Marine Chemistry, 2017, 192, pp.2231. 10.1016/j.marchem.2017.03.006 . hal-02336829

\section{HAL Id: hal-02336829 \\ https://hal.science/hal-02336829}

Submitted on 29 Oct 2019

HAL is a multi-disciplinary open access archive for the deposit and dissemination of scientific research documents, whether they are published or not. The documents may come from teaching and research institutions in France or abroad, or from public or private research centers.
L'archive ouverte pluridisciplinaire $\mathbf{H A L}$, est destinée au dépôt et à la diffusion de documents scientifiques de niveau recherche, publiés ou non, émanant des établissements d'enseignement et de recherche français ou étrangers, des laboratoires publics ou privés. 


\title{
Trace metal limitations (Co, $\mathrm{Zn}$ ) increase $\mathrm{PIC} / \mathrm{POC}$ ratio in coccolithophore Emiliania huxleyi
}

\author{
Marie Boye*, Mohamed A. Adjou, Gabriel Dulaquais, Paul Tréguer \\ Laboratoire des Sciences de l'Environnement Marin (CNRS UMR 6539) \\ Institut Universitaire Européen de la Mer \\ Place Nicolas Copernic
}

FR- 29280 Plouzané

Boye et al., 2017. Marine Chemistry, 192, 22-31

http://dx.doi.org/10.1016/j.marchem.2017.03.006

*Corresponding author: Marie Boye - Present address: Laboratoire d'Océanographie et du Climat: Expérimentations et Approches Numériques (CNRS UMR 7159), Université Pierre et Marie Curie, 4 Place Jussieu, 75005 PARIS, France - Email:

marie.boye@locean.upmc.fr

Keywords: trace metals (Zn, Co, Cd), Emiliania huxleyi, growth/calcification/photosynthesis, PIC/POC ratio, biological carbon pump. 
Abstract

The effect of cobalt (Co), zinc (Zn) or cadmium (Cd) availability on the growth and particulate inorganic (PIC) to organic (POC) carbon ratio of the cosmopolitan coccolithophore Emiliania huxleyi was examined using batch cultures. Growth co-limitation by Co and Zn occurred at low free metal ion concentrations below 10-12 pM. The two metals could replace one another in biochemical functions: full replacement of Zn by Co was possible, but the $20 \%$ higher growth rate observed with high Co levels in the absence of $\mathrm{Zn}$ than observed in the presence of high Zn but no added Co suggested that there was an absolute growth requirement of Co that could only partly be met by Zn. In contrast, Cd had no effect on growth in the absence of Co and Zn, indicating that this strain cannot use $\mathrm{Cd}$ under these conditions. The colimitation by inorganic Co and $\mathrm{Zn}$ led to highly calcified cells containing a large quota of nitrogen, but diminished organic carbon content, likely due to a lower photosynthetic production rate. Deficiency of $\mathrm{Zn}$ and Co cofactors could have dramatically decreased the activity of carbonic anhydrase, lowering $\mathrm{CO}_{2}$ availability for photosynthesis. In contrast to the large decreases in carbon fixation rates at low $\mathrm{Zn}$ and $\mathrm{Co}$ ion concentrations, calcification rates were unaffected at low $\mathrm{Zn}$ levels and were only minimally decreased by low Co. As a result the PIC:POC ratios in E. huxleyi increased by up to 8-fold under $\mathrm{Zn}$ limitation and 3-5-fold under Co limitation to values where coccolithophores act as a source of atmospheric $\mathrm{CO}_{2}$. As a result, low $\mathrm{Co}$ and Zn availability in seawater could affect the efficiency of the biological carbon pump, and atmospheric $\mathrm{CO}_{2}$ levels. Thus, the impact of $\mathrm{Co}$ and $\mathrm{Zn}$ limitation may need to be considered to improve assessments of the impact of $E$. huxleyi and other biogenic calcifiers on oceanic sequestration of $\mathrm{CO}_{2}$. 


\section{Introduction}

Our understanding of the effects of zinc (Zn), cobalt (Co) and cadmium (Cd)

3 on oceanic productivity and the biological carbon pump is still limited, although we 4 know these trace metals to be essential in many biochemical functions of phytoplankton (Frausto da Silva and Williams, 2000). They are indeed involved in a large variety of crucial functions, such as DNA-replication (Zn-fingers) and enzyme activation, Zn being present in 300 enzymes (Vallee and Auld, 1990) and Cd in a native carbonic anhydrase in marine diatoms (Lane et al., 2005). They are also involved in the structure of vitamins, in which Co acts as a cofactor in vitamin $B_{12}$ (Kobayashi and Shimizu, 1999). Furthermore, the three metals, especially Zn, are linked to carbon metabolism through their involvement in the functioning and regulation of the enzyme carbonic anhydrase (CA) for utilization of bicarbonate, which is by far the most ubiquitous chemical species of inorganic carbon in ambient seawater (Morel et al., 1994; Yee and Morel, 1996). This enzyme accelerates the otherwise slow rate of conversion of bicarbonate into carbon dioxide $\left(\mathrm{CO}_{2}\right)$, which is fixed in photosynthesis by Rubisco (Buitenhuis et al., 1999), and is an essential component of cellular $\mathrm{CO}_{2}$ pumps. This enzyme may also be involved in the production of carbonate (Dreybrodt et al., 1997) used for calcification. Carbonic anhydrase occurs in most phytoplankton, including the cosmopolitan coccolithophore Emiliania huxleyi (Nimer et al., 1994; Nielsen, 1995; Riebesell et al., 1993).

Despite the higher abundance of $\mathrm{Zn}, \mathrm{Co}$, and $\mathrm{Cd}$ in E. huxleyi than in diatoms (Sunda and Huntsman, 1995, 2000; Ho et al., 2003; Twining and Baines, 2013), little is known about the effect of these metals on the growth of these calcifying species. For instance, the proportional biological utilization of dissolved $\mathrm{Co}$ and $\mathrm{Cd}$, and the macronutrient phosphate (P) reported in different oceanic regions (de Baar et al., 1994; Saito et al., 2010; Boye et al., 2012; Dulaquais et al., 2014a) hints at these metals playing a key role in bloom-forming phytoplankton, notably in the blooms occupied seasonally by Emiliania huxleyi (Brown and Yoder, 1994). Culture experiments have also shown that the growth rate of coccolithophores can be limited by low free ion concentrations of $\mathrm{Co}$ and $\mathrm{Zn}$, with maximum growth rates and sensitivities to metal limitation differing among species and strains (Brand et al., 1983; Sunda and 32 Huntsman, 1992; Lee and Morel, 1995; Sunda and Huntsman, 1995; Yee and Morel, 33 1996). Emiliania huxleyi requires co to achieve maximum growth rate but this 34 requirement is often only partly be met by $\mathrm{Zn}$, an effect that appears to be strain specific (XU et al., 2007). In contrast, the inter-replacement of Co and $\mathrm{Zn}$ in most biochemical functions appears to be a general attribute of the E. huxleyi species (Sunda and Huntsman, 1995; Xu et al., 2007). Intriguingly, E. huxleyi has a relatively 
1 high internal quota of $\mathrm{Cd}$ compared with other phytoplankton (Sunda and 2 Huntsman, 1995, 2000; Ho et al., 2003), whereas there is no identified biochemical native $\mathrm{Cd}$ function in this species. Additions of $\mathrm{Cd}$ have been shown to alleviate growth limitation by $\mathrm{Co}$ or $\mathrm{Zn}$, by replacing some biochemical functions in E. huxleyi (Lee and Morel, 1995; Xu et al., 2007). However, there might be a minimum Zn or Co requirement that $\mathrm{Cd}$ cannot replace; hence, substitution of $\mathrm{Cd}$ for $\mathrm{Zn}$ or Co would only occur once this minimum requirement was fulfilled (XU et al., 2007). To elucidate the effects of potential interplays of $\mathrm{Co}, \mathrm{Zn}$ and $\mathrm{Cd}$ on growth of E. huxleyi; we first need to gain a better understanding of their individual effects.

Despite their role in the activation of carbonic anhydrase, only a very few studies have investigated the interactions between these metals and coccolithophore carbon metabolism, including the acquisition of inorganic carbon and production of organic carbon by photosynthesis and calcite by biomineralization. These studies partially investigated only the effect of $Z n$ in E. huxleyi (Buitenhuis et al., 2003; Schulz et al., 2004), while the impact of Co and Cd on the carbon quotas and rates of calcification has not been examined. For instance, it has been suggested that $\mathrm{Cd}$ concentrations could modulate the calcification rate of $E$. huxleyi when the primary Zn requirement is met, but this might not be a general trend in coccolithophores ( $X \cup$ et al., 2007). Variations in inorganic Zn levels have been shown to modify the efficiency of bicarbonate utilization by $E$. huxleyi, suggesting a pivotal role of $\mathrm{Zn}$ in modulating the activity of the carbonic anhydrase (Buitenhuis et al., 2003). Another study reported that low inorganic Zn concentrations led to the accumulation of calcite in E. huxleyi due to the decoupling of the growth limitation from the calcification rate (which was unaffected), with consequences for oceanic carbon cycling (Schultz et al., 2004). An increase in calcite content under Zn limitation can indeed impact the ratio of particulate inorganic to organic carbon export (e.g. the rain ratio), which is one of the factors determining $\mathrm{CO}_{2}$ sequestration in the deep ocean (Archer, 1991; Ridgwell et al., 2009). It can also impact the export of carbon from the photic zone through ballasting of particulate organic carbon by calcite

30 (Armstrong et al., 2002; Klaas and Archer, 2002). Some factors that control the 31 production of organic and inorganic carbon in coccolithophores have been 32 identified, such as elevated seawater $\mathrm{CO}_{2}$ (acidification), which can increase overall 33 photosynthesis (Beardall and Raven, 2004) but reduce calcification (Riebesell et al., 34 2000; Findlay et al., 2011; Krug et al., 2011). Another factor is global warming and 35 consequent macronutrient limitation of phytoplankton growth (Riegman et al., 2000; 36 Langer et al., 2012; Gerecht et al., 2014). However, inorganic carbon acquisition for 37 photosynthesis and calcification in coccolithophores is still a puzzle, to which the 
1 three metals could offer a vital part of the solution through their involvement in

2 carbonic anhydrase.

3 In this study, we examined the effect of $\mathrm{Zn}, \mathrm{Co}$ and $\mathrm{Cd}$ on the growth of $E$. 4 huxleyi in culture experiments designed to provide a quantitative basis for 5 extrapolating to oceanic conditions. The three trace metals were tested separately 6 to avoid trace metal substitution. We also investigated their impact on cellular 7 carbon quotas (organic and inorganic) and on photosynthesis and calcification 8 rates, to further assess their effect on carbon metabolism in E. huxleyi.

\section{Material and Methods}

\subsection{Cultures}

Emiliania huxleyi (strain CCMP371, clone 12-1) was obtained from the Provasoli-Guillard National Center for Marine Algae and Microbiota (Bigelow Laboratory for Ocean Sciences, West Boothbay Harbour, Maine, USA). This calcifying and axenic strain originating from the Sargasso Sea was maintained at $17^{\circ} \mathrm{C}$ in $f / 50$ medium. Emiliania huxleyi is a spherical unicellular haptophyte with a diameter ranging between 4 and $7 \mu \mathrm{m}$.

Experiments were conducted in batch culture in ultraclean and sterile conditions. Procedures for the cleaning and sterilisation of bottles and other equipment were as described in Sunda and Huntsman (1995). Chelexed synthetic seawater (Aquil) was prepared as described in Price et al. (1988/1989), and used for the culture medium at $f / 50$ macronutrient concentrations with a mix of vitamin $B_{12}$, biotin and thiamine added to a final concentration of $0.08 \mathrm{nM}, 0.2 \mathrm{nM}$, and $60 \mathrm{nM}$, respectively. Experiments were conducted in duplicate in 2-L polycarbonate NALGENE ${ }^{\circledR}$ bottles at $15^{\circ} \mathrm{C}$ at a photon flux density of $200 \mu \mathrm{E} \mathrm{m}^{-2} \mathrm{~s}^{-1}$ on a $14 / 10$ hours light/dark cycle. Ethylenediaminetetraacetic acid (EDTA) was used to control free trace metal ion concentrations in the media.

Cultures were bubbled continuously with filtered ambient air. Before the experiments were started, cells were conditioned to limiting metal concentrations by re-inoculating the cultures six times into new medium without $\mathrm{Zn}, \mathrm{Co}$ and $\mathrm{Cd}$ additions. The cells were then transferred into experimental conditions 3 to 4 times during exponential growth until they reached a steady growth rate. Once cellular growth rate was steady, cultures were sampled during the exponential growth phase in the middle of the daily light period. 


\subsection{Trace metal speciation and ranges}

In EDTA-containing culture media, dissolved trace metals were present as dissolved inorganic metal species and metal chelates with EDTA. As the metal-EDTA chelates are unavailable for metal uptake in such media, metal uptake and associated physiological effects are determined by the concentration of highly buffered dissolved inorganic metal species or free aquated metal ions. In the present work, we chose to relate our results to the free ion concentrations of the three metals studied (Co, Zn, and Cd) for easy comparison with previous studies.

Concentrations of the free metal ions $\left[\mathrm{Zn}^{2+}\right],\left[\mathrm{CO}^{2+}\right]$ and $\left[\mathrm{Cd}^{2+}\right]$ were calculated from the total metal concentrations using an equilibrium complexation model that we adapted from MINEQL+. The stability constants of the metal-EDTA complexes, as well as those of inorganic metals complexes, were defined from the IUPAC database of physical constants (Pettit and Powell, 2001). These constants were corrected for the ion activity coefficients in seawater (Millero and Pierrot, 1998). The computed ratio of free ionic metal to the total concentrations of the metal (mol mol1) was 10-3.97 for $\mathrm{Zn}, 10^{-3.77}$ for $\mathrm{Co}$, and 10-3.70 for $\mathrm{Cd}$. Background metal concentrations in the synthetic seawater cleaned through Chelex were checked using HR-ICP-MS measurements with an Element 2 (Rodushkin and Ruth, 1997), and yielded undetectable values since they were below the detection limit of the analyses (e.g., [Zn] $<0.02 \mathrm{pM}$; [Co] $<0.03 \mathrm{pM}$; [Cd] $<0.04 \mathrm{pM}$ ). The free metal ion contribution from the initial media before the addition of EDTA was thus considered negligible.

To avoid artefacts from the potential substitution of one metal for another in certain enzymes, single metal additions were conducted without the two non-tested metals. Six concentrations were then selected for each metal. The trace metal stock solutions were made by diluting atomic absorption standard solutions (SIGMAALDRICH) with deionized and distilled water (18 M $\Omega$ MilliQ). The EDTA concentration was $100 \mu \mathrm{M}$ in the final media. The selected range of concentrations for the trace metals encompassed the range of metal concentrations found in surface seawater (Bruland, 1992; Ellwood and van den Berg, 2000; Ellwood and van den Berg, 2001; Ellwood, 2004; Ellwood et al., 2005; Bown et al., 2011; Boye et al., 2012; Dulaquais et al., 2014a) and was based on previous culture experiments using E. huxleyi (Sunda and Huntsman, 1995; Buitenhuis et al., 2003). The concentrations tested for $\left[\mathrm{CO}^{2+}\right]$ were: $0.05,0.20,0.45,3.05,11.70$ and $63.75 \mathrm{pM}$; for $\left[\mathrm{Zn}^{2+}\right]: 0.20,0.40,1.00,6.00,10.00$ and $37.00 \mathrm{pM}$; and for $\left[\mathrm{Cd}^{2+}\right]$ : $0.20,0.40,1.00,6.00,10.00$ and $48.00 \mathrm{pM}$. A positive

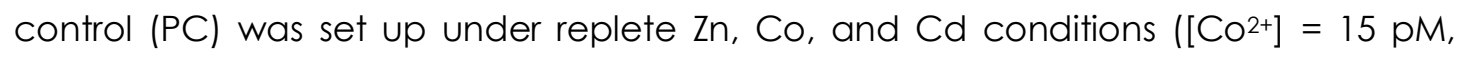
$\left[\mathrm{Zn}^{2+}\right]=20 \mathrm{pM}$, and $\left.\left[\mathrm{Cd}^{2+}\right]=13 \mathrm{pM}\right)$. Additionally, a negative control (NC) was set up 
1 to test the impact of $\mathrm{Zn}, \mathrm{Cd}$ and Co starvation, so E. huxleyi was acclimated

2 gradually to the medium without additions of any of these three metals for more than

3 four generations. Another three experiments were also conducted to examine the

4 physiological response of E. huxleyi to the direct addition of metals. These three

5 experiments were made by individually adding one of the three metals at replete

6 concentration to a culture previously conditioned to grow in media to which none of

7 the three metals had been added (e.g.; cultures acclimated to deplete conditions).

\subsection{Growth rate}

Cells were counted daily using both a Beckman Coulter (Z2 Coulter Counter) and an optical microscope. The growth rate $\left(\mu\right.$; in day $\left.{ }^{-1}\right)$ was then calculated as the slope of the following linear-equation:

$$
\operatorname{Ln}(d)=\mu^{*}++B
$$

where $t$ is the time of incubation (in day), $d$ the cell density (in cells $/ \mathrm{mL}$ ) and $B$ the $y$ intercept ( Ln (d) at to).

\subsection{Cellular contents and rates of calcification and photosynthesis}

Total particulate carbon (TPC), particulate organic carbon (POC) and particulate organic nitrogen (PON) were analysed from a sample of 100 to $500 \mathrm{ml}$ (depending on the cell density) of the culture filtered onto glass fiber filters (Whatman GF/F) precombusted at $450^{\circ} \mathrm{C}$ for 4 hours. The filters were stored at $-20^{\circ} \mathrm{C}$, and dried for 12 hours at $60^{\circ} \mathrm{C}$ before analyses. POC and PON were analysed after fuming of the filter with concentrated $\mathrm{HCl}$ for $4 \mathrm{~h}$ in a desiccator and drying at $60^{\circ} \mathrm{C}$ in an oven as described in Le Moigne et al. (2013). POC and PON were measured using a Carlo Erba Analyzer 1500. TPC was analysed using the same protocol and method, but without fuming the filters. The concentrations of particulate inorganic carbon (PIC) were estimated from the difference between TPC and POC, and represented the amount of calcium carbonate $\left(\mathrm{CaCO}_{3}\right)$ in E. huxleyi (Schulz et al., 2004). Production rates of calcium carbonate by calcification and of POC by photosynthesis were then estimated by multiplying the specific growth rate by the cellular quotas of PIC and POC, respectively. Owing to the experimental approach used in this work, growth rates and cellular carbon contents did not change significantly over the course of the experiment, thus allowing such estimates.

Chlorophyll-a (Chl-a) was determined after filtration of 50 to $100 \mathrm{ml}$ of culture on GF/F filters. The filters were placed in $90 \%(\mathrm{v} / \mathrm{v})$ acetone/water and homogenized in a cell for a minimum of $4 \mathrm{~h}$ followed by a centrifugation. Chl-a level was then 
1 measured by fluorescence detection using a TURNER Design 10-AN Fluorimeter. The

2 detection limit for Chl-a measurement was $0.075 \mathrm{mgL}^{-1}$. Chl-a analyses were

3 calibrated with pure Chl-a from spinach (Sigma) and concentrations were

4 calculated according to Lorensen (1966).

\subsection{Statistical analysis}

All experiments were performed in duplicate, and analyses were performed twice in each replicate bottle. The standard errors reported ( \pm S.E.) are thus based on an average of four measurements. Paired two-tailed t-tests were used to test the data for significant differences between pairs of means at the $95 \%$ confident interval $(p<0.05)$.

\section{Results and discussion}

\subsection{Effect on growth}

We examined the impact of free $\mathrm{Zn}^{2+}, \mathrm{CO}^{2+}$, or $\mathrm{Cd}^{2+}$ concentrations on the growth of E. huxleyi separately, in the absence of the other two metals (Table 1). The growth rates $(\mu)$ obtained at the various ion concentrations of $Z n$ seemed to fit with a saturation curve, unlike the growth rates recorded at the various $\mathrm{Cd}^{2+}$ concentrations, which remained constant and low (Table 1). The growth rates plotted as a function of log $\left(\mathrm{Me}^{2+}\right)$ showed a sigmoid curve for $\mathrm{CO}^{2+}$ (Figure 1), suggesting that the model saturation equation may actually not fit the data at low $\mathrm{Co}^{2+}$. The curvature observed at these low levels could suggest that there is a minimum $\mathrm{Co}^{2+}$ requirement for growth.

The maximum specific growth rates $\left(\mu_{\max }\right)$ and the half-saturation constant values of $\mathrm{Me}^{2+}\left(\mathrm{K}_{\mathrm{m}}\right)$ obtained when $\mu=\mu_{\max } / 2$ were estimated by using non-linear regression method of the growth rates as the function of $\mathrm{Me}^{2+}$ concentrations. The maximal growth rate of $E$. huxleyi obtained with this method for $\mathrm{CO}^{2+}\left(\mu_{\text {max-Co }}=0.71 \mathrm{~d}^{-1}\right)$ was reduced by $50 \%$ at Co ion concentrations below $0.55 \mathrm{pM}\left(\mathrm{K}_{\mathrm{m}-\mathrm{Co}}\right)$. Cell division was also severely reduced by low free $\mathrm{Zn}^{2+}$ levels below the $\mathrm{K}_{\mathrm{m}-\mathrm{zn}}$ value of $0.51 \mathrm{pM}$, but led to a lower maximum growth rate with replete $\mathrm{Zn}^{2+}$ conditions above 10-11 pM $\left(\mu_{\text {max-zn }}=0.57 \mathrm{~d}^{-1}\right)$ compared with replete $\mathrm{Co}^{2+}$ levels above $12 \mathrm{pM}$ (Figure 1). The halfsaturation constants obtained for $\mathrm{Zn}$ and $\mathrm{Co}$ in these experiments are in good agreement with previous studies using other strains of E. huxleyi (Sunda and Huntsman, 1995; Schulz et al., 2004; Xu et al., 2007). The growth rate of the E. huxleyi strain we used (strain CCMP371) was co-limited by $\mathrm{CO}^{2+}$ and $\mathrm{Zn}^{2+}$ since both free metal ion concentrations needed to be reduced to very low values to limit growth 
1 rate to near-zero values. Furthermore, the addition of either $\mathrm{Co}^{2+}$ or $\mathrm{Zn}^{2+}$ at $\mathrm{a}$ 2 sufficiently high concentration to cultures of E. huxleyi acclimated to deplete conditions drove a rapid increase (in less than 1-2 days) in the growth rate to values akin to the maximal values observed in the kinetic growth curves under Co-replete or Zn-replete conditions (Figure 1). This result suggests that E. huxleyi could benefit from an input in $\mathrm{Co}^{2+}$ or $\mathrm{Zn}^{2+}$ for growing, even after a long period of starvation.

The $20 \%$ higher growth rate observed with high $\mathrm{Co}^{2+}$ levels in the absence of $\mathrm{Zn}$ than observed in the presence of high $\mathrm{Zn}^{2+}$ but no added Co (Figure 1) suggests that there was an absolute growth requirement of Co that could only partly be met by $\mathrm{Zn}$. Location and possible inter-substitution of $\mathrm{Co}$ and $\mathrm{Zn}$ in important biomolecules in $\mathrm{E}$. huxleyi are reported in Table 2. Because Co and $\mathrm{Zn}$ had the ability to substitute for each other (partially or fully), the co-limitation of the growth by $\mathrm{Co}^{2+}$ and $\mathrm{Zn}^{2+}$ was a type II colimitation (biochemical substitution co-limitation) according to Saito et al. (2008b). A similar specific requirement for Co for optimal growth that can only be partly met by Zn has been previously reported for other strains of E. huxleyi (Sunda and Huntsman, 1995; Jakuba et al., 2008a). For some other strains, however, the maximum growth rate produced a similar value with either Co or Zn (XU et al., 2007), suggesting that the use and requirement of $\mathrm{Co}$ and $\mathrm{Zn}$ could be strain dependant.

In the $\mathrm{Cd}$ experiments without added $\mathrm{Zn}$ and $\mathrm{Co}$, the growth rate remained low $\left(\mu_{\text {max }-\mathrm{Cd}}=0.07 \mathrm{~d}^{-1}\right.$ ) regardless of the $\mathrm{Cd}^{2+}$ concentration (Figure 1). This growth rate was similar to the negative control treatment in which cells were grown without any of these three metals added to the medium ( $\mu_{\mathrm{Nc}}=0.06 \mathrm{~d}^{-1}$; Figure 1). Thus, Cd had no impact on the growth of the CCMP371 strain in the absence of $\mathrm{Zn}$ and Co. This apparent lack of a $\mathrm{Cd}$ requirement for $E$. huxleyi is unexpected since this species has previously been seen to have a relatively large quota of Cd (Sunda and Huntsman, 2000; Ho et al., 2003). The often nearly linear relationship between dissolved $\mathrm{Cd}$ and phosphate observed in the ocean (Boyle et al., 1976; Frew and Hunter, 1992; Boye et al., 2012) also suggests that phytoplankton have a biological requirement for $\mathrm{Cd}$, as has been demonstrated for a diatom for the activation of a $\mathrm{Cd}$-specific carbonic anhydrase (CDCA 1; Lane et al., 2005). However, there is still no in vivo evidence of the use of $\mathrm{Cd}$ in a known biochemical function in E. huxleyi (Table 2). Nevertheless, a previous study indicated that Cd can partially substitute for Zn or Co in several E. huxleyi strains, once the minimum requirement for $\mathrm{Zn}$ or $\mathrm{Co}$ has been fulfilled (XU et al., 2007). Because of this, we do not exclude the non-viability of some E. huxleyi cells in Cd-experiments due to the absence of subsistence levels of Zn and Co. Our Cdexperiments suggest that the relatively high cellular $\mathrm{Cd}$ quota measured in coccolithophores (Sunda and Huntsman, 1995, 2000; Ho et al., 2003; Xu et al., 2007) 
1 does not necessarily indicate biochemical utilization of $\mathrm{Cd}$. For instance, the

2 accumulation of $\mathrm{Cd}$ could be the effect of $\mathrm{Zn}$-transporters being unable to 3 differentiate $\mathrm{Cd}$ from $\mathrm{Zn}$ (and thus transporting $\mathrm{Cd}$ into the cell), as has been found

4 previously in E. huxleyi (Sunda and Huntsman 2000).

\subsection{Effect on cellular organic contents}

The cellular content of organic carbon (POC) decreased significantly (t-test, $\mathrm{p}$ $<0.01, n=4$ ) with decreasing $\mathrm{Co}^{2+}$ concentration from a plateau (t-test, $\mathrm{p}<0.05, \mathrm{n}=$ 4) of about $12.8 \mathrm{pg} \mathrm{C}$ cell-1 $^{-1}$ at roughly $3 \mathrm{pM} \mathrm{Co}^{2+}$ (Table 1; Figure 2a). It also decreased significantly (t-test, $\mathrm{p}<0.01, \mathrm{n}=4$ ) with decreasing $\mathrm{Zn}^{2+}$ concentration from a maximum of $18.9 \mathrm{pg} \mathrm{C}$ cell-1 at roughly $6 \mathrm{pM} \mathrm{Zn}^{2+}$. Although the organic content also seemed to decrease progressively from this maximum down to $14.1 \mathrm{pg}$ $C$ cell- $^{-1}$ with increasing $\mathrm{Zn}^{2+}$ levels, this decrease was not significant (t-test, $p>0.23, n=$ 4). The change in POC quota at low $\mathrm{CO}^{2+}$ or $\mathrm{Zn}^{2+}$ levels was accompanied by a similar change in POC production (Table 1; Figure 2b). The production of POC indeed decreased significantly (t-test, $\mathrm{p}<0.01, \mathrm{n}=4$ ), with decreasing $\mathrm{CO}^{2+}$ or $\mathrm{Zn}^{2+}$ concentration from maxima of 8.2 and $9.2 \mathrm{pg} \mathrm{C} \mathrm{cell-1}^{-1}$ at $12 \mathrm{pM} \mathrm{Co}^{2+}$ and $10 \mathrm{pM}$ $\mathrm{Zn}^{2+}$, respectively (Figure 2b). Hence, the observed decrease in cellular POC content was due to an impact on production rate of POC by photosynthesis, whereby slow growing cells became empty of organic carbon under these $\mathrm{Co}^{2+}$ or $\mathrm{Zn}^{2+}$ deplete conditions. Light limitation can similarly lead to a decrease in organic production by E. huxleyi, resulting, for example, in a decline of its cellular lipid content, which amounts to 45 to $60 \%$ of cellular POC, by a factor of 2.5 (Fernandez et al., 1996). The effect of low $\mathrm{Zn}^{2+}$ and $\mathrm{CO}^{2+}$ on organic carbon production suggests that these metals could play a key role in the photosynthesis process. It is unlikely that this role is due to a change in chlorophyll-a synthesis since similar Chl-a levels $(\sim 0.13$ pg cell-1) were detected independently of these metal concentrations (Table 1). Among the important biomolecules in E. huxleyi in which $\mathrm{Zn}$ and Co are involved and/or substitute each other (Table 2), it has been suggested that a significant portion of the cellular quota of $\mathrm{Zn}$ and $\mathrm{Co}$ in eukaryotic phytoplankton can actually serve as a cofactor for carbonic anhydrase (CA) (Saito et al., 2008b). The CA in the chloroplasts of $E$. huxleyi (Nimer et al., 1994) converts $\mathrm{HCO}_{3}$ into $\mathrm{CO}_{2}$ at the site of $\mathrm{CO}_{2}$ fixation by Rubisco, the first enzyme involved in assimilation of $\mathrm{CO}_{2}$ in the Calvin cycle of photosynthesis. Because Rubisco has a low affinity for $\mathrm{CO}_{2}$ and because dissolved $\mathrm{CO}_{2}$ ordinarily represents less than $1 \%$ of the total dissolved inorganic carbon (DIC) in seawater, the binding of $\mathrm{CO}_{2}$ to Rubisco can often constitute the limiting step in photosynthesis. On the other hand, $\mathrm{HCO}_{3}$ represents about $90 \%$ of the $\mathrm{DIC}$ in seawater and the conversion of $\mathrm{HCO}_{3}^{-}$to $\mathrm{CO}_{2}$ by $\mathrm{CA}$ can maintain high rates of 
1 inorganic carbon fixation by Rubisco, even under the low dissolved $\mathrm{CO}_{2}$

2 concentrations in seawater. This mechanism, which would involve activation of CA by

3 a cofactor to supply $\mathrm{CO}_{2}$ for photosynthesis, was first hypothesized by Buitenhuis et al.

4 (2003) who tested Zn and bicarbonate co-limitation on E. huxleyi. The decline we

5 observed in the production of POC at low Zn and Co concentrations can, therefore,

6 be conceivably due to low availability of $\mathrm{CO}_{2}$ for photosynthesis, since the deficiency

7 of Zn and Co cofactor would dramatically decrease the CA activity. Interestingly,

8 higher organic carbon content and production rate were generally found with $\mathrm{Zn}$

9 rather than with Co (Figure 2a-b), suggesting an overall higher CA affinity for $\mathrm{Zn}$ in

10 strain CCMP371. Furthermore, the absence of $\mathrm{Cd}$ effect on cellular POC production

11 in the absence of $\mathrm{Zn}$ and Co (Table 1) suggests that this strain did not have a CA

12 homologous to that of diatom CDCA1, which is known to use Cd (Lane et al., 2005).

13 The absence of CDCA1-like has been also observed in another four strains of $E$.

14 huxleyi (Park et al. 2007). Our result also suggests that Cd cannot replace Zn or Co in

15 the CA, in line with the DNA sequencing of $\delta$-EhCA1 in E. huxleyi (Soto et al., 2006)

16 that is a close homologue of TWCA1 found in diatoms and known to use Zn or Co as

17 a cofactor (Roberts et al., 1997).

18 Contrary to organic carbon, nitrogen accumulation was observed in the cells 19 (t-test, $\mathrm{p}<0.01$ ) at low concentrations of $\mathrm{Co}^{2+}$ and $\mathrm{Zn}^{2+}$ (Figure $2 \mathrm{c}$ ). Indeed, the 20 amount of organic nitrogen per cell (PON) increased by about 3 times when $\mathrm{CO}^{2+}$ 21 and $\mathrm{Zn}^{2+}$ decreased from 3 and $1 \mathrm{pM}$ to 0.05 and $0.2 \mathrm{pM}$, respectively. The 22 decoupling of growth (Figure 1) from organic nitrogen synthesis likely led to this 23 accumulation under $\mathrm{Co}$ and $\mathrm{Zn}$ deplete conditions. The acquisition of nitrogen was 24 probably not affected by growth limitation by $\mathrm{Co}$ and $\mathrm{Zn}$. Similar accumulation of 25 organic nitrogen was previously observed in E. huxleyi grown under low Zn conditions 26 (Schulz et al., 2004).

As a result of $\mathrm{PON}$ accumulation and $\mathrm{POC}$ decline, the organic $\mathrm{N}$ to $\mathrm{C}$ ratio 28 increased significantly (t-test, $\mathrm{p}<0.01$ ) when growth was $\mathrm{CO}^{2+}$ and $\mathrm{Zn}^{2+}$ limited (Figure $292 \mathrm{2d}$ ). Severe limitation by $\mathrm{CO}^{2+}$ and $\mathrm{Zn}^{2+}$ indeed led to $\mathrm{a} \sim 6$ fold increase in PON/POC 30 ratio from $0.05-0.06 \mathrm{~mol} \mathrm{~N}$ per mol C up to $0.37 \mathrm{~mol} \mathrm{~N}$ per mol C (Table 1). The N/C 31 ratios of $E$. huxleyi reported in the literature range broadly from 0.07 to $0.27 \mathrm{~mol} \mathrm{~N}$ per 32 mol C, depending on the study conditions and strain (Fernandez et al., 1996; 33 Biddanda and Benner, 1997; Buitenhuis et al., 1999; Ho et al., 2003; Leonardos and 34 Geider, 2005). Our experiments demonstrate a significant shift in the N/C 35 stoichiometry of $E$. huxleyi with metal availability, due to a change in $C$ metabolism. 
The amount of inorganic carbon per cell (PIC) increased significantly (t-test, $p$ $<0.01, n=4$ ) at low concentrations of either $\mathrm{Zn}^{2+}$ or $\mathrm{Co}^{2+}$, rising from $\sim 10 \mathrm{pg} \mathrm{C}$ cell-1 at

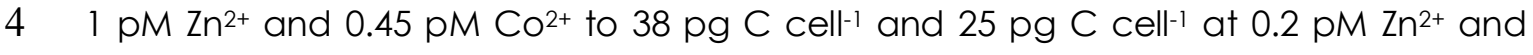
$50.05 \mathrm{pM} \mathrm{Co}^{2+}$, respectively (Figure 3a). Scanning electron microscope pictures showed that the increase in PIC per cell at low $\mathrm{CO}^{2+}$ and $\mathrm{Zn}^{2+}$ concentrations resulted from an increase in the number of coccoliths per cell, which accumulated around the coccosphere (Figure 4). The increase in the amount of calcite per cell observed at low $\mathrm{Zn}^{2+}$ concentrations was consistent with the previous findings of Schulz et al. (2004).

Contrary to the cellular PIC content, the production rate of calcite was 12 significantly lower (t-test, $\mathrm{p}<0.01, \mathrm{n}=4$ ) from 6.5 to $3 \mathrm{pg} \mathrm{C}$ cell-1 $\mathrm{d}^{-1}$ under reduced $13 \mathrm{Co}^{2+}$ availability, while the effect of $\mathrm{Zn}^{2+}$ concentrations on the calcification rate was statistically not significant (t-test, $p>0.1, n=6$ ) (Figure 3b). Therefore, E. huxleyi was producing less calcite under $\mathrm{Co}^{2+}$ limitation, whereas this species became simultaneously more heavily calcified under this condition (Figure $3 \mathrm{~b}$ ). The severe decline of growth under low $\mathrm{CO}^{2+}$ conditions (Figure 1) exceeded the $\sim 2$ fold limiting effect on calcite production (Figure 3b), which likely led to the accumulation of inorganic carbon under $\mathrm{CO}^{2+}$ limitation (Figure $3 \mathrm{a}$ ). The decline of inorganic carbon production rate under limiting $\mathrm{CO}^{2+}$ conditions suggested a direct or indirect role of $C o$ in the calcification process. Physiological studies are necessary to understand this potential role, especially to examine whether Co could be involved in the production of carbonate $\left(\mathrm{CO}_{3}{ }^{2-}\right)$ used for calcification through the activation of a carbonic anhydrase (Dreybrodt et al., 1997).

Because calcite accumulated while cellular organic carbon decreased with decreasing metal availability, the PIC/POC ratio was much higher (ratio >1-2) under $\mathrm{Zn}^{2+}$ and $\mathrm{Co}^{2+}$ limitation, compared with replete conditions (ratio <1) (Figure 3c; Table 1). Coccolithophores act as a source of atmospheric $\mathrm{CO}_{2}$ at a cellular PIC/POC ratio above 1 (Balch et al., 1991; Buitenhuis et al., 1996; Rost and Riebesell, 2004), and limitation by $\mathrm{Zn}^{2+}$ and $\mathrm{CO}^{2+}$ could, therefore, lead to a positive feedback on rising atmospheric $\mathrm{CO}_{2}$. Increasing $\mathrm{CO}_{2}$ concentration (i.e., decreasing $\mathrm{pH}$ ) led to the opposite trend in E. huxleyi PIC/POC ratio compared with metal limitation, due to an overall decrease in calcification (Riebesell et al., 2000; Zondervan et al., 2001, 2002). Warming can also decrease this ratio in coccolithophores to values lower than 1 by reducing calcification (Gerecht et al., 2014). However, the effect of pH and probably temperature is likely not a general trend for all species and morphotypes of $E$. huxleyi 37 (Langer et al., 2006, 2009; Iglesias-Rodriguez et al., 2008). Such individual responses of 
1 coccolithophores to trace metal availabilities still need to be assessed. For instance,

2 the rather high PIC/POC ratio (>5) obtained in the absence of both Zn and Co (Table

3 1) could hint at strong sensitivity of this strain to the supply of these metals, especially

4 for photosynthesis.

\section{Possible oceanic implications}

Culture experiments would suggest that coccolithophores tend to primarily require Co rather than $\mathrm{Zn}$ to attain high growth rates and would therefore be more abundant in oceanic waters with high Co concentrations and Co/Zn ratios (Sunda and Huntsman, 1995). However, the limitation of E. huxleyi by Co and Zn may be difficult to demonstrate in the field, partly because these two metals may interreplace each other in cellular components. In addition, the chemical speciation of these two trace metals is still poorly documented in seawater (Tables 3 and 4), although organic complexation is thought to dominate their chemical speciation (Ellwood and van den Berg, 2000, 2001; Saito and Moffett, 2001; Bown et al., 2012). The bioavailability of the different dissolved chemical forms in seawater is also unknown, complicating the extrapolation of results obtained in EDTA-containing media to the natural system. Despite these limitations, comparison of the halfsaturation constant for $\mathrm{Co}^{2+-l i m i t e d}$ growth obtained in this study $(0.55 \mathrm{pM})$ with the free ion concentrations of cobalt $\left(\mathrm{CO}^{2+}\right)$ that have been estimated in the surface waters in different biogeochemical domains of the oceans (Table 3) indicated the potential for $\mathrm{CO}^{2+}$ availability to strongly limit the growth of $E$. huxleyi in the subtropical Atlantic, especially at its south-western and north-eastern sides (sub-femtomolar $\mathrm{Co}^{2+}$ levels), and possibly in the southern branch of the Antarctic Circumpolar Current (ACC) south of the Polar Front (femtomolar $\mathrm{CO}^{2+}$ levels). Likewise, the reduction of the growth observed below $10 \mathrm{pM} \mathrm{Zn}^{2+}$ (Figure 1) compared with the free ion concentrations of zinc measured in surface oceanic waters (Table 4) maintains the possibility for $\mathrm{Zn}^{2+}$ limitation in the subtropical waters of the north Atlantic (<10 pM) and the subantarctic waters of the Pacific $(<1$ pM). In addition, growth limitation by Zn likely occurs in the subarctic Pacific, since Zn additions stimulated phytoplankton growth in deck incubation experiments run in these waters, and had the largest effect on the growth of $E$. huxleyi and other coccolithophores compared with other phytoplankton types tested (Crawford et al., 2003). Further studies examining the organic speciation of $\mathrm{Co}$ and $\mathrm{Zn}$ would be required to confirm and extend these trends. However, based on the observations available to date, the low levels of free ion concentrations of both $\mathrm{Co}$ and $\mathrm{Zn}$ in subtropical waters (generally $<10$ pM) suggest that E. huxleyi could be severely co-limited at these latitudes, notably 
1 co-limitation by $\mathrm{Zn}$ and Co could also occur in the subarctic Pacific, since Zn

2 additions were seen to stimulate the growth of coccolithophores in these waters

3 (Crawford et al., 2003). Likewise, the replacement of $\mathrm{Co}^{2+}(<0.006 \mathrm{pM})$ by $\mathrm{Zn}^{2+}(>44$

$4 \mathrm{pM})$ in the southern $\mathrm{ACC}$, and the substitution of $\mathrm{Zn}^{2+}(<0.5 \mathrm{pM})$ by $\mathrm{CO}^{2+}(3-17 \mathrm{pM})$ in

5 subantarctic waters could alleviate the limitation by either $\mathrm{CO}^{2+}$ or $\mathrm{Zn}^{2+}$ in the Southern

6 Ocean. The ability to replace the limiting metal would give a competitive advantage

7 to the taxa (Sunda and Hunstman, 1995), with consequences for phytoplankton

8 community structure and productivity. For instance, E. huxleyi would be severely

9 limited in low Zn and Co environments in our experiments, whereas diatoms that can

10 commonly replace $\mathrm{Zn}$ by $\mathrm{Cd}$ would still benefit from high $\mathrm{Cd}$ concentrations (Lane 11 and Morel, 2000), such as in the Antarctic Circumpolar Current (Boye et al., 2012).

In addition to the low $\mathrm{Co}^{2+}$ and $\mathrm{Zn}^{2+}$ concentrations observed in the subtropics

13 (Tables 3-4), these oligotrophic waters are characterized by extremely low 14 concentrations of macronutrients (Moore et al., 2008). There, the N/P ratio can be 15 below the Redfield ratio, suggesting that nitrogen can become limiting before phosphorus (Dulaquais et al., 2014b). Because E. huxleyi tends to accumulate PON under low $\mathrm{Co}^{2+}$ and $\mathrm{Zn}^{2+}$ availability by continuing to use dissolved $\mathrm{N}$ substrates (e.g., 18 nitrate) to synthesize organic nitrogen (Figure 2), its limitation by $\mathrm{N}$ could therefore be intensified in subtropical waters due to $\mathrm{CO}^{2+}$ and $\mathrm{Zn}^{2+}$ limitation. Similarly, warming of sea-surface waters can intensify P-limitation of coccolithophores due to a higher Prequirement for maintaining growth and POC production rates (Gerecht et al., 2014).

22 Growth limitation by Co and Zn could, on the other hand, inhibit the biological utilization of organic phosphorus in oligotrophic waters by decreasing the activity of Zn/Co alkaline phosphatase enzymes (Shaked et al., 2006; Jakuba et al., 2008a). The likelihood of changes in metal input and macronutrient supply in the changing ocean can in turn alleviate or exacerbate these multiple and additional limitations. Long time-series of atmospheric and oceanic observations will be very important for examining such changes in the future. This will help to determine the patterns of abundance and occurrence of this major phytoplankton group.

The trends of PIC/POC observed at limiting conditions of $\mathrm{CO}^{2+}$ and $\mathrm{Zn}^{2+}$ can also impact the carbon cycle in extremely low $\mathrm{Co}^{2+}$ and $\mathrm{Zn}^{2+}$ areas such as subtropical waters and likely subarctic waters, by inducing an increase in the $\mathrm{CaCO}_{3}$ content and a decrease in the POC content of $E$. huxleyi, therefore altering the ratio of $\mathrm{CaCO}_{3}$ to POC. The overall effect would be a decrease in the $\mathrm{CO}_{2}$ storage capacity of the upper ocean by the lowering of surface water alkalinity and the driving of a $\mathrm{CO}_{2}$ efflux back to the atmosphere. Furthermore, an increase in the $\mathrm{PIC} / \mathrm{POC}$ ratio can induce shifts in the calcite ballasting effect (Klaas and Archer, 
$12002)$ by increasing the density of sinking cellular particles at low $\mathrm{Zn}^{2+}$ and $\mathrm{Co}^{2+}$ but, at 2 the same time, lowering the amount of POC per PIC transported to depth. 3 Intensification of metal inputs to limited areas would in turn promote photosynthesis of 4 E. huxleyi by increasing the activity of carbonic anhydrase. Its PIC/POC ratio would 5 thus decrease and the atmospheric $\mathrm{CO}_{2}$ fixed by photosynthesis would increase, 6 both constituting a negative feedback on rising atmospheric $\mathrm{CO}_{2}$. Since low metal 7 availability would act against high $\mathrm{CO}_{2}$ in surface waters (i.e., acidification) for 8 atmospheric $\mathrm{CO}_{2}$ sequestration by $E$. huxleyi, the removal of metal limitation due, for 9 instance, to increasing inputs in the changing ocean, would act in concert, and 10 possibly amplify, the effect of acidification for atmospheric $\mathrm{CO}_{2}$ sequestration. 11 However, the higher seawater $\mathrm{CO}_{2}$ concentrations reached under acidification 12 could actually alleviate the limiting step of $\mathrm{CO}_{2}$ binding to Rubisco for photosynthesis, 13 therefore lowering the need for $\mathrm{Zn}$ and $\mathrm{Co}$ in order to activate a carbonic anhydrase. 14 Thus, change in these metal inputs may need to be studied together with 15 acidification to further highlight the synergic effect of climate change on the $16 \mathrm{PIC} / \mathrm{POC}$ ratio of this major producer of pelagic calcite, and to better anticipate feedbacks of the biological carbon pump on rising atmospheric $\mathrm{CO}_{2}$.

\section{Conclusions}

Shifts in $\mathrm{CO}^{2+}$ and $\mathrm{Zn}^{2+}$ availability could cause changes not only in growth but also in cellular contents of organic and inorganic carbon in Emiliania huxleyi. The metabolic effect of Co, and especially $\mathrm{Zn}$, could be to modulate the activity of the carbonic anhydrase (CA) in the chloroplast and, thus, the supply of $\mathrm{CO}_{2}$ for Rubisco, which is used in photosynthesis to produce organic carbon. The availability of $\mathrm{CO}^{2+}$ could additionally modulate the calcification, either directly or indirectly, but other studies are necessary in order to understand the potential underlying process. The effect of limitation by $\mathrm{CO}^{2+}$ and $\mathrm{Zn}^{2+}$ was an increase of the PIC/POC ratio in $\mathrm{E}$. huxleyi, which in turn decreases the efficiency of the ocean's biological $\mathrm{CO}_{2}$ pump. Reciprocally, the alleviation of these limitations promoted growth and photosynthesis of E. huxleyi and decreased its PIC/POC ratio, which would likely stimulate the biological $\mathrm{CO}_{2}$ pump. The likelihood of change in metal inputs into the surface ocean may thus need to be considered when assessing future change in the efficiency of the biological carbon pump due to this major phytoplankton producer of pelagic calcite. Metal speciation and its evolution in the changing ocean will also need to be considered in order to improve our understanding of changes in metal bioavailability and potential feedbacks on the PIC/POC ratio. Finally, since Co and Zn limitation could lead to opposite trends in the PIC/POC ratio of E. huxleyi to that of ocean acidification, the sensitivity of $E$. huxleyi to the combined effects of acidification and 
1 changes in Co and Zn inputs to surface waters will also need to be addressed. For 2 instance, it is possible that the co-limitation by $\mathrm{Co}^{2+}$ and $\mathrm{Zn}^{2+}$ is alleviated at higher 3 partial pressure of $\mathrm{CO}_{2}$ due to higher availability of $\mathrm{CO}_{2}$ for Rubisco, but this question 4 requires further investigation.

\section{Acknowledgements}

7 We gratefully acknowledge Annick Masson (LEMAR) for her assistance with the CHN8 analyses. This work was supported by the CAMAÏEUD project (carbon and metals 9 interactions with E. huxleyi and diatoms) funded by the French National LEFE-CYBER 10 program of INSU-CNRS. The University of Western Brittany supported M. Adjou's PhD 11 fellowship within the European Network of Excellence EUR-OCEANS and G. Dulaquais' 12 PhD fellowship with the Brittany Region within LABEX-MER. 


\section{References}

Archer, D., 1991. Modeling the calcite lysocline. J. Geophysical Research, 96, 1703717050.

Armstrong, R.A., Lee, C., Hedges, J.I., Honjo, S., Wakeham, S.G., 2002. A new, mechanistic model for organic carbon fluxes in the ocean based on the quatitative association of POC with ballast minerals. Deep Sea Res. Part II, 49, 219-236.

Baars, O., \& Croot, P. L. (2011). The speciation of dissolved zinc in the Atlantic sector of the Southern Ocean. Deep Sea Research Part II: Topical Studies in Oceanography, 58(25), 2720-2732.

Baars, O., \& Croot, P. L. (2014). Dissolved cobalt speciation and reactivity in the eastern tropical North Atlantic. Marine Chemistry, 173, 310-319.

Balch, W.M., Holligan, P.M., Ackleson, S.G., 1991. Biological and optical properties of mesoscale coccolithophore blooms in the Gulf of Maine. Limnolo. \& Oceanogragr., 36, 629-643.

Beardall, J., Raven, J.A., 2004. The potential effects of global climate change on microalgal photosynthesis, growth and ecology. Phycologia, 43, 26-40.

Berg, J.M., Shi, Y., 1996. The galvanization of biology: A growing appreciation for the roles of zinc. Science, 271, 1081-1085.

Biddanda, B., Bernner, R., 1997. Carbon, nitrogen, and carbohydrate fluxes during the production of particulate and dissolved organic matter by marine phytoplankton. Limnology and Oceanography, 42 (3), 506-518.

Bown, J., Boye, M., Nelson, D. M. (2012). New insights on the role of organic speciation in the biogeochemical cycle of dissolved cobalt in the southeastern Atlantic and the Southern Ocean. Biogeosciences, 9, 2719-2736.

Bown, J., Boye, M., Baker, A., Duvieilbourg, E., Lacan, F., Le Moigne, F., Planchon, F., Speich, S., Nelson, D.M., 2011. The biogeochemical cycle of dissolved cobalt in the Atlantic and the Southern Ocean south off the coast of South Africa. Marine Chemistry 126, 193-206.

Boye, M., Wake, B. D., Lopez Garcia, P., Bown, J., Baker, A. R., Achterberg, E. P., 2012. Distributions of dissolved trace metals $(\mathrm{Cd}, \mathrm{Cu}, \mathrm{Mn}, \mathrm{Pb}, \mathrm{Ag})$ in the southeastern 
Atlantic and the Southern Ocean. Biogeosciences, 9, 3231-3246.

Boyle, E.A., Sclater, F., Edmond, J.M., 1976. On the marine geochemistry of cadmium. Nature, 263, 42-44.

Brand, L.E., Sunda, W.G., Guillard, R.R.L., 1983. Limitation of marine-phytoplankton reproductive rates by zinc, manganese, and iron. Limnology and Oceanography, 28 (6), $1182-1198$.

Brown, C.W., Yoder, J.A., 1994. Coccolithophorid blooms in the global ocean. Journal of Geophysical Research, 99 (C4), 7467-7482.

Bruland, K.W., 1980. Oceanographic distributions of cadmium, zinc, nickel, and copper in the North Pacific. Earth and Planetary Science Letters, 47 (2), 176-198.

Bruland, K.W., 1989. Complexation of zinc by natural organic ligands in the central North Pacific. Limnology and Oceanography, 34, 269-285.

Bruland, K.W., 1992. Complexation of cadmium by natural organic ligands in the central North Pacific. Limnol. \& Oceanography, 37 (5), 1008-1017.

Buitenhuis, E.T., Timmermans, K.R., de Baar, H.J.W., 2003. Zinc-bicarbonate colimitation of Emiliania huxleyi. Limnology and Oceanography 48, 1575-1582.

Buitenhuis, E.T., van Bleijswijk, J., Bakker, D., Veldhuis, M., 1996. Trends in inorganic and organic carbon in a bloom of Emiliania huxleyi in the North Sea. Mar. Ecol.-Prog. Ser., $143,271-282$.

Buitenhuis, E.T., de Baar, H.J.W., Veldhuis, M., 1999. Photosynthesis and calcification by Emiliania huxleyi (Prymnesiophyceae) as a function of inorganic carbon species. J. Phycol., 35, 949-959.

Carlucci, A.F., Bowes, P.M., 1970. Vitamin production and utilization by phytoplankton in mixed culture. Journal of Phycology, 6, 393-400.

Crawford, D.W., Lipsen, M.S., Purdie, D.A., Lohan, M.C., Statham, P.J., Whitney, F.A., Putland, J.N., Johnson, W.K., Sutherland, N., Peterson, T.D., Harrison, P.J., Wong, C.S., 2003. Influence of Zinc and Iron Enrichments on Phytoplankton Growth in the Northeastern Subarctic Pacific. Limnology and Oceanography, 48 (4), 1583-1600.

De Baar, H.J.W., Saager, P.M., Nolting, R.F., Van der Meer, J., 1994. Cadmium versus Phosphate in the World Ocean. Marine Chemistry, 46 (3), 261-281. 
Donat, J. R., \& Bruland, K. W. (1990). A comparison of two voltammetric techniques for determining zinc speciation in Northeast Pacific Ocean waters. Marine Chemistry, 28(4), 301-323.

Dreybrodt, W., Eisenlohr, L., Madry, B. Ringer, S., 1997. Precipitation kinetics of calcite in the system $\mathrm{CaCO}_{3}-\mathrm{H}_{2} \mathrm{O}-\mathrm{CO}_{2}$ : The conversion to $\mathrm{CO}_{2}$ by the slow process $\mathrm{H}^{+}+\mathrm{HCO}_{3}{ }^{-}$ $\rightarrow \mathrm{CO}_{2}+\mathrm{H}_{2} \mathrm{O}$ as a rate limiting step. Geochimica et Cosmochimica Acta, 61 (18), 3897-3904.

Dulaquais, G., Boye, M., Middag, R., Owens, S., Puigcorbe, V., Buesseler, K., Masqué, P., de Baar, H.J.W., Carton, X., 2014a. Contrasting biogeochemical cycles of cobalt in the surface western Atlantic Ocean. Global Biogeochemical Cycles 10.1002/2014GB004903.

Dulaquais, G., Boye, M., Rijkenberg, M. J. A., \& Carton, X. J., 2014b. Physical and remineralization processes govern the cobalt distribution in the deep western Atlantic Ocean. Biogeosciences, 11 (6), 1561-1580.

Dulaquais, G., Gourain, A., Boye, M. (in preparation). The organic speciation of dissolved cobalt in relation with the atmospheric deposition in the surface Western Atlantic.

Ellwood, M. J. (2004). Zinc and cadmium speciation in subantarctic waters east of New Zealand. Marine Chemistry, 87(1), 37-58.

Ellwood, M. J., van den Berg, C.M.G., 2001. Determination of organic complexation of cobalt in seawater by cathodic stripping voltammetry. Marine Chemistry, 75 (1-2), 3347.

Ellwood, M.J., 2004. Zinc and cadmium speciation in subantarctic waters east of $\mathrm{New}$ Zealand. Marine Chemistry, 87 (1-2), 37-58.

Ellwood, M.J., van den Berg, C.M.G., 2000. Zinc speciation in the Northeastern Atlantic Ocean. Marine Chemistry, 68 (4), 295-306.

Ellwood, M.J., van den Berg, C.M.G., Boye, M., Veldhuis, M.J.W., de Jong, J.T.M., de Baar H.J.W., Croot, P.L., Kattner, G., 2005. Organic complexation of cobalt across the Antarctic Polar Front in the Southern Ocean. Marine and Freshwater Research, 56 (8), 1069-1075. 
Fernandez, E., Fritz, J., Balch, W.M., 1996. Chemical composition of the coccolithophorid Emiliania huxleyi under light-limited steady state growth. Journal of Experimental Marine Biology and Ecology, 207 (1-2), 149-160.

Findlay, H.S., Calosi, P., Crawfurd, K., 2011. Determinants of the PIC:POC response in the coccolithophore Emiliania huxleyi under future ocean acidification scenarios. Limnol. \& Oceanogr., 56, 1168-1178.

Frausto da Silva, J.J.R., and Williams, R.J.P., 2000. The biological chemistry of the elements. Oxford Univ. Press.

Gabrielli, P., Barbante, C., Boutron, C., Cozzi, G., Gaspari, V., Planchon, F., Ferrari, C., Turetta, C., Hong, S., Cescon P., 2005.Variations in atmospheric trace elements in Dome C (East Antarctica) ice over the last two climatic cycles. Atmospheric Environment, 39 (34), 6420-6429.

Gerecht, A.C., Supraha, L., Edvardsen, B., Probert, I., Henderoks, J., 2014. High temperature decreases the PIC/POC ratio and increases phosphorus requirements in Coccolithus pelagicus (Haptophyta). Biogeosciences discussion, 11, 1021-1051.

Ho, T.-Y., Quigg, A., Finkel, Z.V., Milligan, A.J., Wyman, K., Falkowski, P.G., Morel, F.M.M., 2003. The elemental composition of some marine phytoplankton. Journal of Phycology, 39 (6), 1145-1159.

Hudson, R.J.M., Morel, F.M.M., 1993. Trace metal transport by marine microorganisms: Implications of metal coordination kinetics. Deep-Sea Research I, 40 (1), 129-150.

Iglesias-Rodriguez, M.D., Halloran, P.R., Rickaby, R.E.M., Hall, I.R., Colmenero-Hidolgo, E., Gittins, J.R., et al., 2008. Phytoplankton calcification in a High- $\mathrm{CO}_{2}$ World, Science, $320,336-340$.

Jakuba, R.W., Moffett, J.W. Dyhrman, S.T., 2008a. Evidence for the linked biogeochemical cycling of zinc, cobalt, and phosphorus in the western North Atlantic Ocean. Global Biogeochemical Cycles, 22, GB4012.

Jakuba, R. W., Moffett, J. W., Saito, M. A., 2008b. Use of a modified, high-sensitivity, anodic stripping voltammetry method for determination of zinc speciation in the North Atlantic Ocean. Analytica chimica acta, 614(2), 143-152.

Jakuba, R. W., Saito, M. A., Moffett, J. W., XU, Y. (2012). Dissolved zinc in the subarctic North Pacific and Bering Sea: Its distribution, speciation, and importance to primary producers. Global Biogeochemical Cycles, 26(2). 
Kim, T., Obata, H., Kondo, Y., Ogawa, H., Gamo, T., 2015a. Distribution and speciation of dissolved zinc in the western North Pacific and its adjacent seas. Marine Chemistry, $173,330-341$.

Kim, T., Obata, H., Gamo, T., 2015b. Dissolved Zn and its speciation in the northeastern Indian Ocean and the Andaman Sea. Frontiers in Marine Science, 2, 60.

Klaas, C., Archer, D., 2002. Association of sinking organic matter with various types of mineral ballast in the deep sea: Implications for the rain ratio. Global Biogeochemical Cycles, 16. GB1116.

Kobayashi, M., Shimizu, S., 1999. Cobalt proteins. Eur. J. Biochem., 261 (1), 1-9.

Krug, S.A., Schulz, K.G., Riebesell, U., 2011. Effects of changes in carbonate chemistry speciation on Coccolithus braarudii: a discussion of coccolithophorid sensitivities. Biogeosciences, 8, 771-777.

Lane, T.W., Morel, F.M.M., 2000. A biological function for cadmium in marine diatoms. Proceedings of the National Academy of Sciences, 97, 4627-4631.

Lane, T.W., Saito, M.A., George, G.N., Pickering, I.J., Prince R.C., Morel, F.M.M., 2005. A cadmium enzyme from a marine diatom. Nature, 435, 42.

Langer, G., Nehrke, G., Probert, I., Ly, J., Zivery, P., 2009. Strain-specific responses of Emiliania huxleyi to changing seawater carbonate chemistry. Biogeosciences, 6 , 2637-2646.

Langer, G., Geisen, M., Baumann, K.-H., Klaes, J., Riebesell, U., Thomas, S., and Young, J. R., 2006. Species-specific responses of calcifying algae to changing seawater carbonate chemistry. Geochem. Geophy. Geosy., 7, 1-12.

Langer, G., Oetjen, K., and Brenneis, T., 2012. Calcification of Calcidiscus leptoporus under nitrogen and phosphorus limitation. J. Exp. Mar. Biol. Ecol., 413, 131-137.

Le Moigne, F.A.C., Boye, M. Masson, A., Corvaisier, R., Grossteffan, E., Gueneugues, A., Pondaven, P., 2013. Description of the biogeochemical features of the subtropical southeastern Atlantic and the Southern Ocean south of South Africa during the austral summer of the International Polar Year. Biogeosciences, 10, 281-295.

Lee, J.G., Morel, F.M.M., 1995. Replacement of zinc by cadmium in marine phytoplankton. Marine Ecology Progress Series, 27, 305-309. 
Leonardos, N., Geider, R.J., 2005. Elevated atmospheric $\mathrm{CO}_{2}$ increases organic carbon fixation by Emiliania huxleyi (Haptophyta) under nutrient-limited, high-light conditions. Journal of Phycology, 41 (6), 1196-1203.

Lohan, M. C., Crawford, D. W., Purdie, D. A., Statham, P. J. (2005). Iron and zinc enrichments in the northeastern subarctic Pacific: Ligand production and zinc availability in response to phytoplankton growth. Limnology and Oceanography, 50(5), 1427-1437.

Lorensen, C.J., 1966. A method for the continuous measurement of in vivo chlorophyll concentration. Deep Sea Research, 13, 223-227.

Martin, J.H., Fitzwater, S.E., Gordon, R.M., Hunter, C.N., Tanner, S.J., 1993. Iron, primary production and carbon-nitrogen flux studies during JGOFS North Atlantic Bloom Experiment. Deep Sea Research II, 40 (1-2), 115-134.

Martin, J.H., Gordon, R.M., Fitzwater, S., Broenkow, W.W., 1989. VERTEX: phyłoplankton studies in the Gulf of Alaska. Deep Sea Research A, 36, 649-680.

Millero, F.J., Pierrot, D., 1998. A chemical equilibrium model for natural waters. Aquatic Geochemistry, 4 (1), 153-199.

Morel, F.M.M., Reinfelder, J.G., Roberts, S.B., Chamberlain, C.P., Lee, J.G., Yee, D., 1994. Zinc and carbon colimitation of marine phytoplankton. Nature 369, 740-742.

Muller, F. L., Gulin, S. B., Kalvøy, Å. (2001). Chemical speciation of copper and zinc in surface waters of the western Black Sea. Marine Chemistry, 76(4), 233-251.

Nielsen, M.V., 1995. Photosynthetic characteristics if the coccolithophorid Emiliania huxleyi (prymenesiophycea) exposed to elevated concentrations of dissolved inorganic carbon. Journal of phycology, 31 (5), 7-15.

Nimer, N.A., Guan, Q., Merrett, M.J., 1994. Extra and intra-cellular carbonic anhydrase in relation to culture age in a high-calcifying strain of Emiliania huxleyi Lohmann. New Phytologist, 126, 601-607.

Noble, A. E., Lamborg, C. H., Ohnemus, D. C., Lam, P. J., Goepfert, T. J., Measures, C. I., Saito, M. A. (2012). Basin-scale inputs of cobalt, iron, and manganese from the Benguela-Angola front to the South Atlantic Ocean. Limnology and Oceanography, 57(4), 989-1010.

Noble, A. E., Saito, M. A., Maiti, K., Benitez-Nelson, C. R. (2008). Cobalt, manganese, and iron near the Hawaiian Islands: A potential concentrating mechanism for cobalt 
within a cyclonic eddy and implications for the hybrid-type trace metals. Deep Sea Research Part II: Topical Studies in Oceanography, 55(10), 1473-1490.

Paasche, E., 2002. A review of the coccolithophorid Emiliania huxleyi (Prymnesiophyceae), with particular reference to growth, coccolith formation, and calcification-photosynthesis interactions. Phycologia, 40, 503-529.

Park, H., Song, B., Morel, F.M.M., 2007. Diversity of the cadmium-containing carbonic anhydrase in marine diatoms and natural waters. Environmental Microbiology, 9, 403413.

Pettit, L.D., Powell, K.J., 2001. IUPAC Stability Constants Database (IUPAC and Academic Software, Otley).

Price, N.M, Morel, F.M.M., 1990. Cadmium and cobalt substitution for zinc in a marine diatom. Nature, 344, 658-660.

Price, N.M., Harisson, G.I., Hering, J.G., Hudson, R.J., Nirelp, M.V., Palenik, B., Morel F.M.M., 1988/1989. Preparation and chemistry of the artificial algal culture medium Aquil. Biological Oceanography, 6 (5-6), 443-461.

Ridgwell, A., Schmidt, D. N., Turley, C., Brownlee, C., Maldonado, M. T., Tortell, P., Young, J. R., 2009. From laboratory manipulations to Earth system models: scaling calcification impacts of ocean acidification. Biogeosciences, 6, 2611-2623.

Riebesell, U., Wolf-Gladrow, D.A., Smetacek, V., 1993. Carbon dioxide limitation of marine phytoplankton growth rates. Nature, 361, 249-251.

Riebesell, U., Zondervan, I., Rost, B., Tortell, P. D., Zeebe, R. E., Morel, F. M. M., 2000. Reduced calcification of marine plankton in response to increased atmospheric $\mathrm{CO}_{2}$, Nature, 407, 5, 364-367.

Riegman, R., Stolte, W., Noordeloos, A. A. M., and Slezak, D., 2000. Nutrient uptake and alkaline phosphatase (EC3:1:3:1) activity of Emiliania huxleyi (Prymnesiophyceae) during growth under $\mathrm{N}$ and $\mathrm{P}$ limitation in continuous cultures. J. Phycol., 36, 87-96.

Roberts, S.B., Lane, T.W., Morel, F.M.M., 1997. Carbonic anhydrase in the marine diatom Thalassiosira weissflogii (Bacillariophyceae). Journal of Phycology, 33, 845-850.

Rodushkin, I., Ruth, T., 1997. Determination of trace metals in estuarine and sea-water reference materials by high resolution inductively coupled plasma mass spectrometry. Journal of analytical atomic spectrometry, 12 (10), 1181-1185. 
Rost, B. and Riebesell, U., 2004. Coccolithophores and the biological pump: responses to environmental changes. In: Coccolithophores - from molecular processes to global impact, edited by: Thierstein, H. R. and Young, J. R., Springer, Heidelberg, Germany, 99-126.

Saito, M. A., Moffett, J. W., DiTullio, G. R. (2004). Cobalt and nickel in the Peru upwelling region: A major flux of labile cobalt utilized as a micronutrient. Global Biogeochemical Cycles, 18(4).

Saito, M. A., Rocap, G., Moffett, J. W. (2005). Production of cobalt binding ligands in a Synechococcus feature at the Costa Rica upwelling dome. Limnology and Oceanography, 50(1), 279-290.

Saito, M.A., Goepfert, T.J., 2008a. Zinc-cobalt colimitation of Phaeocystis antarctica. Limnology and Oceanography, 53 (1), 266-275.

Saito, M.A., Goepfert, T.J., Ritt, J.T., 2008b. Some thoughts on the concepts of colimitation: three definition and the importance of biovailability. Limnology and Oceanography, 53 (1), 276-290.

Saito, M.A., Moffett, J.W., 2001. Complexation of cobalt by natural organic ligands in the Sargasso Sea as determined by a new high-sensitivity electrochemical cobalt speciation method suitable for open ocean work. Marine Chemistry, 75 (1-2), 49-68.

Saito, M. A., Goepfert, T. J., Noble, A. E., Bertrand, E. M., Sedwick, P. N., DiTullio, G. R., 2010. A seasonal study of dissolved cobalt in the Ross Sea, Antarctica: micronutrient behavior, absence of scavenging, and relationships with $\mathrm{Zn}, \mathrm{Cd}$, and $\mathrm{P}$. Biogeosciences, 7, 4059-4082.

Schulz, K.G., Zondervan, I., Gerringa, L.J.A., Timmermans, K.R., Veldhuis, M.J.W., Riebesell, U., 2004. Effect of trace metal availability (Fe and Zn) on coccolithophorid calcification. Nature, 430, 673-676.

Shaked, Y., XU, Y., Leblanc, K., Morel, F.M.M., 2006. Zinc availability and alkaline phosphatase activity in Emiliania huxleyi: Implications for $\mathrm{Zn}-\mathrm{P}$ co-limitation in the ocean. Limnol. Oceanogr., 51 (1), $299-309$.

Soto, A.R., Zheng, H., Shoemaker, D., Rodriguez, J., Read, B.A., Wahlund, T.M., 2006. Identification and preliminary characterization of two CDNAs encoding unique carbonic anhydrases from the marine alga Emiliania huxleyi. Applied and Environmental Microbiology, 72, 5500-5511. 
Sunda, W.G., Huntsman, S.A., 1992. Feedback interactions between zinc and phytoplankton in seawater. Limnology and Oceanography, 37 (1), 25-40.

Sunda, W.G., Huntsman, S.A., 1995. Cobalt and zinc inter-replacement in marine phytoplankton: Biological and geochemical implications. Limnology and Oceanography, 40 (8), 1404-1417.

Sunda, W. G. and Huntsman, S. A., 1998. Processes regulating cellular metal accumulation and physiological effects: phytoplankton as model systems. Sci. Total Environ., 219, 165-181.

Sunda, W.G., Huntsman, S.A., 2000. Effect of Zn, Mn, and Fe on Cd accumulation in phytoplankton: Implications for oceanic Cd cycling. Limnology and Oceanography 45 (7), 1501-1516.

Turner, D.R., Whitfield, M., Dickson, A.G., 1981. The equilibrium speciation of dissolved components in freshwater and seawater at WC and $1 \mathrm{~atm}$ pressure. Geochimica et Cosmochimica Acta, 45, 855-881.

Twining, B. S., \& Baines, S. B., 2013. The trace metal composition of marine phytoplankton. Annual review of Marine Science, 5, 191-215.

Vallee, B.L., Auld, D.S., 1990. Zinc coordination, function, and structure of zinc enzymes and other proteins. Biochemistry, 29, 5647-5659.

Xu, Y., Tang, D., Shaked, Y., Morel, F.M.M., 2007. Zinc, cadmium, and cobalt interreplacement and relative use efficiencies in the coccolithophore Emiliania huxleyi. Limnology and Oceanography, 52 (5), 2294-2305.

Yee, D., Morel, F.M.M., 1996. In vivo substitution of zinc by cobalt in carbonic anhydrase of a marine diatom. Limnology and Oceanography, 41 (3), 573-577.

Zondervan, I., Rost, B., Riebesell, U., 2002. Effect of $\mathrm{CO}_{2}$ concentration on the PIC/POC ratio in the coccolithophore Emiliania huxleyi grown under light-limiting conditions and different daylengths. Journal of Experimental Marine Biology and Ecology, 272 (1), 55-70.

Zondervan, I., Zeebe, R.E., Rost, B., Riebesell, U., 2001. Decreasing marine biogenic calcification: a negative feedback on rising atmospheric $\mathrm{PCO}_{2}$. Global Biogeochemical Cycles, 15 (2), 507-516. 


\section{TABLES}

Table 1. Effect of free metal ion concentrations $\left(\log \left[\mathrm{Zn}^{2+}\right], \log \left[\mathrm{Co}^{2+}\right], \log \left[\mathrm{Cd}^{2+}\right]\right)$ on the growth rate $(\mu)$ of $E$. huxleyi and its cellular concentrations of organic carbon (POC), organic nitrogen (PON), inorganic carbon (PIC) and Chl-a, and on cellular ratios of inorganic to organic carbon (PIC/POC) and organic nitrogen to carbon (PON/POC). The standard deviations of the measurements were calculated on replicate analyses (as explained in the text).

\begin{tabular}{|c|c|c|c|c|c|c|c|c|c|c|}
\hline Experiment & $\log \left[Z n^{2+}\right]$ & $\log \left[\mathrm{Co}^{2+}\right]$ & $\log \left[\mathrm{Cd}^{2+}\right]$ & $\underset{\left(d^{-1}\right)}{\mu}$ & $\begin{array}{l}\mathrm{POC} \\
(\mathrm{pgC} \\
\left.\mathrm{cell}^{-1}\right)\end{array}$ & $\begin{array}{l}\mathrm{PIC} \\
(\mathrm{pgC} \\
\left.\text { cell-1) }^{-1}\right)\end{array}$ & $\begin{array}{l}\text { PON } \\
\text { (pgN } \\
\left.\text { cell-1) }^{-1}\right)\end{array}$ & $\begin{array}{c}\mathrm{PIC} / \mathrm{POC} \\
(\mathrm{mol} \mathrm{C} \\
\left.\mathrm{mol} \mathrm{C}^{-1}\right)\end{array}$ & $\begin{array}{l}\text { PON/POC } \\
\text { (mol N } \\
\mathrm{mol} \mathrm{C}^{-1} \text { ) }\end{array}$ & $\begin{array}{l}\text { Chl-a } \\
\left(10^{-1} \mathrm{pg}\right. \\
\left.\text { cell-1) }^{-1}\right)\end{array}$ \\
\hline \multirow{6}{*}{$\mathrm{Zn}$} & -12.70 & Negl. & Negl. & $\begin{array}{c}0.15 \pm \\
0.01\end{array}$ & $\begin{array}{c}6.74 \pm \\
0.54\end{array}$ & $\begin{array}{c}38.04 \pm \\
3.19\end{array}$ & $\begin{array}{c}2.91 \pm \\
0.33\end{array}$ & $\begin{array}{c}5.64 \pm \\
0.02\end{array}$ & $0.37 \pm 0.01$ & $\begin{array}{c}1.35 \pm \\
0.02\end{array}$ \\
\hline & -12.40 & Negl. & Negl. & $\begin{array}{c}0.29 \pm \\
0.01\end{array}$ & $\begin{array}{r}12.11 \\
\pm 1.53\end{array}$ & $\begin{array}{c}23.27 \pm \\
5.03\end{array}$ & $\begin{array}{c}2.08 \pm \\
0.09\end{array}$ & $\begin{array}{c}1.92 \pm \\
0.66\end{array}$ & $0.15 \pm 0.03$ & $\begin{array}{c}1.35 \pm \\
0.05\end{array}$ \\
\hline & -12.00 & Negl. & Negl. & $\begin{array}{c}0.37 \pm \\
0.01 \\
\end{array}$ & $\begin{array}{r}16.64 \\
\pm 1.15 \\
\end{array}$ & $\begin{array}{c}11.92 \pm \\
0.59 \\
\end{array}$ & $\begin{array}{c}1.06 \pm \\
0.03\end{array}$ & $\begin{array}{c}0.72 \pm \\
0.09\end{array}$ & $0.05 \pm 0.01$ & $\begin{array}{c}1.39 \pm \\
0.06\end{array}$ \\
\hline & -11.22 & Negl. & Negl. & $\begin{array}{c}0.49 \pm \\
0.01\end{array}$ & $\begin{array}{r}18.85 \\
\pm 2.19 \\
\end{array}$ & $\begin{array}{c}13.55 \pm \\
0.77\end{array}$ & $\begin{array}{c}1.10 \pm \\
0.11\end{array}$ & $\begin{array}{c}0.72 \pm \\
0.04\end{array}$ & $0.05 \pm 0.00$ & $\begin{array}{l}1.31 \pm \\
0.06\end{array}$ \\
\hline & -11.00 & Negl. & Negl. & $\begin{array}{c}0.53 \pm \\
0.01\end{array}$ & $\begin{array}{r}16.94 \\
\pm 3.26\end{array}$ & $\begin{array}{c}14.56 \pm \\
2.10\end{array}$ & $\begin{array}{c}1.22 \pm \\
0.06\end{array}$ & $\begin{array}{c}0.86 \pm \\
0.04\end{array}$ & 0.01 & $\begin{array}{c}1.29 \pm \\
0.04\end{array}$ \\
\hline & -10.43 & Negl. & Negl. & $\begin{array}{c}0.57 \pm \\
0.01 \\
\end{array}$ & $\begin{array}{r}14.08 \\
\pm 1.61 \\
\end{array}$ & $\begin{array}{c}10.43 \pm \\
0.54 \\
\end{array}$ & $\begin{array}{c}0.95 \pm \\
0.01 \\
\end{array}$ & $\begin{array}{c}0.74 \pm \\
0.12 \\
\end{array}$ & $0.06 \pm 0.01$ & $\begin{array}{c}1.34 \pm \\
0.01 \\
\end{array}$ \\
\hline \multirow{6}{*}{ Co } & Negl. & -13.33 & Negl. & $\begin{array}{c}0.13 \pm \\
0.01\end{array}$ & $\begin{array}{c}6.68 \pm \\
0.46\end{array}$ & $\begin{array}{c}24.56 \pm \\
2.11\end{array}$ & $\begin{array}{c}2.41 \pm \\
0.57\end{array}$ & $\begin{array}{c}3.68 \pm \\
0.06\end{array}$ & $0.31 \pm 0.04$ & $\begin{array}{c}1.39 \pm \\
0.02\end{array}$ \\
\hline & Negl. & -12.63 & Negl. & $\begin{array}{c}0.20 \pm \\
0.01 \\
\end{array}$ & $\begin{array}{c}6.68 \pm \\
0.55 \\
\end{array}$ & $\begin{array}{c}18.08 \pm \\
1.63 \\
\end{array}$ & $\begin{array}{c}1.42 \pm \\
0.14\end{array}$ & $\begin{array}{c}2.71 \pm \\
0.02 \\
\end{array}$ & 0.03 & $\begin{array}{c}1.34 \pm \\
0.02 \\
\end{array}$ \\
\hline & Negl. & -12.33 & Negl. & $\begin{array}{c}0.30 \pm \\
0.02 \\
\end{array}$ & $\begin{array}{c}8.91 \pm \\
0.24 \\
\end{array}$ & $\begin{array}{c}9.01 \pm \\
1.91 \\
\end{array}$ & $\begin{array}{c}1.04 \pm \\
0.10\end{array}$ & $\begin{array}{c}1.01 \pm \\
0.24\end{array}$ & $0.10 \pm 0.01$ & $\begin{array}{c}1.29 \pm \\
0.06\end{array}$ \\
\hline & Negl. & -11.52 & Negl. & $\begin{array}{c}0.48 \pm \\
0.01\end{array}$ & $\begin{array}{r}12.83 \\
\pm 0.63 \\
\end{array}$ & $\begin{array}{c}10.91 \pm \\
0.62\end{array}$ & $\begin{array}{c}0.81 \pm \\
0.10\end{array}$ & $\begin{array}{c}0.85 \pm \\
0.01\end{array}$ & $0.05 \pm 0.00$ & $\begin{array}{c}1.34 \pm \\
0.01\end{array}$ \\
\hline & Negl. & -10.93 & Negl. & $\begin{array}{c}0.67 \pm \\
0.03 \\
\end{array}$ & $\begin{array}{r}12.23 \\
\pm 0.39 \\
\end{array}$ & $\begin{array}{c}10.03 \pm \\
2.16 \\
\end{array}$ & $\begin{array}{c}0.75 \pm \\
0.06\end{array}$ & $\begin{array}{c}0.82 \pm \\
0.20 \\
\end{array}$ & 0.01 & $\begin{array}{c}1.31 \pm \\
0.00 \\
\end{array}$ \\
\hline & Negl. & -10.20 & Negl. & $\begin{array}{c}0.71 \pm \\
0.02 \\
\end{array}$ & $\begin{array}{r}11.84 \\
\pm 1.03 \\
\end{array}$ & $\begin{array}{c}8.80 \pm \\
1.03 \\
\end{array}$ & $\begin{array}{c}0.69 \pm \\
0.00\end{array}$ & $\begin{array}{c}0.74 \pm \\
0.15 \\
\end{array}$ & $0.05 \pm 0.00$ & $\begin{array}{c}1.34 \pm \\
0.02 \\
\end{array}$ \\
\hline \multirow{6}{*}{$\mathrm{Cd}$} & Negl. & Negl. & -12.70 & $\begin{array}{c}0.06 \pm \\
0.00\end{array}$ & $\begin{array}{c}4.14 \pm \\
0.38\end{array}$ & $\begin{array}{c}27.11 \pm \\
3.91\end{array}$ & $\begin{array}{c}1.44 \pm \\
0.05\end{array}$ & $\begin{array}{c}6.55 \pm \\
0.35\end{array}$ & $0.30 \pm 0.03$ & 1.32 \\
\hline & Negl. & Negl. & -12.40 & $\begin{array}{c}0.07 \pm \\
0.00 \\
\end{array}$ & $\begin{array}{c}3.49 \pm \\
0.40 \\
\end{array}$ & $\begin{array}{c}27.90 \pm \\
3.11 \\
\end{array}$ & $\begin{array}{c}1.51 \pm \\
0.07\end{array}$ & $\begin{array}{c}7.99 \pm \\
1.82\end{array}$ & $0.37 \pm 0.03$ & 1.27 \\
\hline & Negl. & Negl. & -12.00 & $\begin{array}{c}0.07 \pm \\
0.01 \\
\end{array}$ & $\begin{array}{c}3.64 \pm \\
0.35 \\
\end{array}$ & $\begin{array}{c}25.56 \pm \\
2.88 \\
\end{array}$ & $\begin{array}{c}1.26 \pm \\
0.39\end{array}$ & $\begin{array}{c}7.02 \pm \\
0.12 \\
\end{array}$ & $0.30 \pm 0.10$ & 1.30 \\
\hline & Negl. & Negl. & -11.22 & $\begin{array}{c}0.07 \pm \\
0.00\end{array}$ & $\begin{array}{c}4.25 \pm \\
0.07\end{array}$ & $\begin{array}{c}20.71 \pm \\
1.53\end{array}$ & $\begin{array}{c}1.34 \pm \\
0.07\end{array}$ & $\begin{array}{c}4.87 \pm \\
0.44\end{array}$ & $=0.01$ & 1.31 \\
\hline & Negl. & Negl. & -11.00 & $\begin{array}{c}0.07 \pm \\
0.01 \\
\end{array}$ & $\begin{array}{c}4.23 \pm \\
0.61 \\
\end{array}$ & $\begin{array}{c}22.13 \pm \\
0.22 \\
\end{array}$ & $\begin{array}{c}1.27 \pm \\
0.02\end{array}$ & $\begin{array}{c}5.23 \pm \\
0.81\end{array}$ & $0.26 \pm 0.03$ & 1.34 \\
\hline & Negl. & Negl. & -10.32 & $\begin{array}{c}0.07 \pm \\
0.00 \\
\end{array}$ & $\begin{array}{c}4.45 \pm \\
0.10 \\
\end{array}$ & $\begin{array}{c}25.83 \pm \\
2.46\end{array}$ & $\begin{array}{c}1.26 \pm \\
0.03\end{array}$ & $\begin{array}{c}5.80 \pm \\
0.69\end{array}$ & $0.24 \pm 0.01$ & 1.31 \\
\hline $\begin{array}{l}\text { Positive } \\
\text { control } \\
\text { (PC) } \\
\end{array}$ & -10.70 & -10.82 & -10.89 & $\begin{array}{c}0.71 \pm \\
0.01\end{array}$ & $\begin{array}{r}12.89 \\
\pm 1.28\end{array}$ & $\begin{array}{c}9.41 \pm \\
0.31\end{array}$ & $\begin{array}{c}1.05 \pm \\
0.08\end{array}$ & $\begin{array}{c}0.73 \pm \\
0.10 \\
\end{array}$ & $0.07 \pm 0.00$ & $\begin{array}{c}1.31 \pm \\
0.03\end{array}$ \\
\hline $\begin{array}{l}\text { Negative } \\
\text { control } \\
\text { (NC) }\end{array}$ & Negl. & Negl. & Negl. & $\begin{array}{c}0.06 \pm \\
0.00\end{array}$ & $\begin{array}{c}6.48 \pm \\
0.56\end{array}$ & $\begin{array}{c}36.38 \pm \\
0.73\end{array}$ & $\begin{array}{c}2.65 \pm \\
0.19\end{array}$ & $\begin{array}{c}5.61 \pm \\
0.37\end{array}$ & $0.35 \pm 0.01$ & n.d. \\
\hline $\begin{array}{l}\text { Zn } \\
\text { addition } \\
\text { to NC }\end{array}$ & -10.70 & Negl. & Negl. & $\begin{array}{c}0.52 \pm \\
0.01\end{array}$ & $\begin{array}{r}12.94 \\
\pm 0.06\end{array}$ & $\begin{array}{c}10.04 \pm \\
0.63\end{array}$ & $\begin{array}{c}1.12 \pm \\
0.09\end{array}$ & $\begin{array}{c}0.78 \pm \\
0.05\end{array}$ & $0.07 \pm 0.01$ & n.d. \\
\hline $\begin{array}{l}\text { Co } \\
\text { addition } \\
\text { to NC }\end{array}$ & Negl. & -10.82 & Negl. & $\begin{array}{c}0.69 \pm \\
0.02\end{array}$ & $\begin{array}{r}12.32 \\
\pm 0.35\end{array}$ & $\begin{array}{c}9.82 \pm \\
0.32\end{array}$ & $\begin{array}{c}1.15 \pm \\
0.08\end{array}$ & $\begin{array}{c}0.80 \pm \\
0.00\end{array}$ & $0.08 \pm 0.01$ & n.d. \\
\hline $\begin{array}{l}\mathrm{Cd} \\
\text { addition } \\
\text { to } \mathrm{NC}\end{array}$ & Negl. & Negl. & -10.89 & $\begin{array}{c}0.07 \pm \\
0.00\end{array}$ & $\begin{array}{c}4.66 \pm \\
0.75\end{array}$ & $\begin{array}{c}26.44 \pm \\
1.69\end{array}$ & $\begin{array}{c}1.85 \pm \\
0.20\end{array}$ & $\begin{array}{c}5.67 \pm \\
1.30\end{array}$ & $0.34 \pm 0.09$ & n.d. \\
\hline
\end{tabular}


Note: Negl.: negligible concentration ([ $\left.\mathrm{Zn}^{2+}\right]<0.02 \mathrm{pM}$; $\left[\mathrm{Co}^{2+}\right]<0.03 \mathrm{pM}$; $\left.\left[\mathrm{Cd}^{2+}\right]<0.04 \mathrm{pM}\right)$. n.d.; not determined. 
Table 2. Location and substitution of $\mathrm{Co}, \mathrm{Zn}$ and $\mathrm{Cd}$ in important biomolecules of $E$. huxleyi.

\begin{tabular}{|c|c|c|c|}
\hline Biomolecules Metals & Zn & Co & $\mathrm{Cd}$ \\
\hline $\begin{array}{l}\text { Carbonic Anhydrase } \\
\text { (CA) }\end{array}$ & $\begin{array}{l}\text { Cofactor of } \delta \text {-EhCA }]^{\text {(a) }} \\
\text { (closely homologous to } \\
\text { TWCAl }^{\text {(b)) }}\end{array}$ & $\begin{array}{l}\text { Substitution for } \mathrm{Zn} \text { in } \\
\quad \delta \text {-EhCA } 1 \text { (a) }\end{array}$ & $\begin{array}{c}\text { No role } \\
\text { (not homologous to } \\
\text { CDCA 1 (c) in E. huxleyi (d)) }\end{array}$ \\
\hline $\begin{array}{l}\text { Alkaline Phosphatase } \\
\text { (AP) }\end{array}$ & Cofactor of $\mathrm{AP}(\mathrm{e}, \mathrm{f})$ & Substitution for $\mathrm{Zn}$ in $\mathrm{AP}$ (f) & No known role \\
\hline Zinc Fingers & $\begin{array}{l}\text { DNA- and RNA-binding } \\
\text { proteins*(g,h) }\end{array}$ & No known role & No known role \\
\hline $\begin{array}{l}\text { Cyanocobalamin } \\
\text { (vitamine } B_{12} \text { ) }\end{array}$ & $\begin{array}{c}\text { No role } \\
\text { (exclusively Co-containing } \\
\text { vitamin) }\end{array}$ & $\begin{array}{l}\text { Central atom of } \mathrm{B}_{12} \\
\text { synthesized by } \\
\text { coccolithophorids(i) }\end{array}$ & $\begin{array}{c}\text { No role } \\
\text { (exclusively Co-containing } \\
\text { vitamin) }\end{array}$ \\
\hline
\end{tabular}

(a) Soto et al. 2006; (b) Roberts et al. 1997; (c) Lane et al.2005; (d) Park et al. 2007; (e) Shaked et al. 2006; (f) Jakuba et al. 2008a; (g) Vallee and Auld, 1990; (h) Berg and Shi, 1996; (i) Carlucci and Bowes, 1970.

* for eukaryotes 
Table 3. Organic speciation of cobalt in the worldwide surface ocean: concentrations of dissolved cobalt (DCo), inorganic cobalt (Co'), free cobalt ions $\left(\mathrm{CO}^{2+}\right)$, organic cobalt-binding ligand (LCo), and conditional stability constant of $\mathrm{CoL}$ complexes $\left(K^{\prime} \mathrm{Col}\right)$.

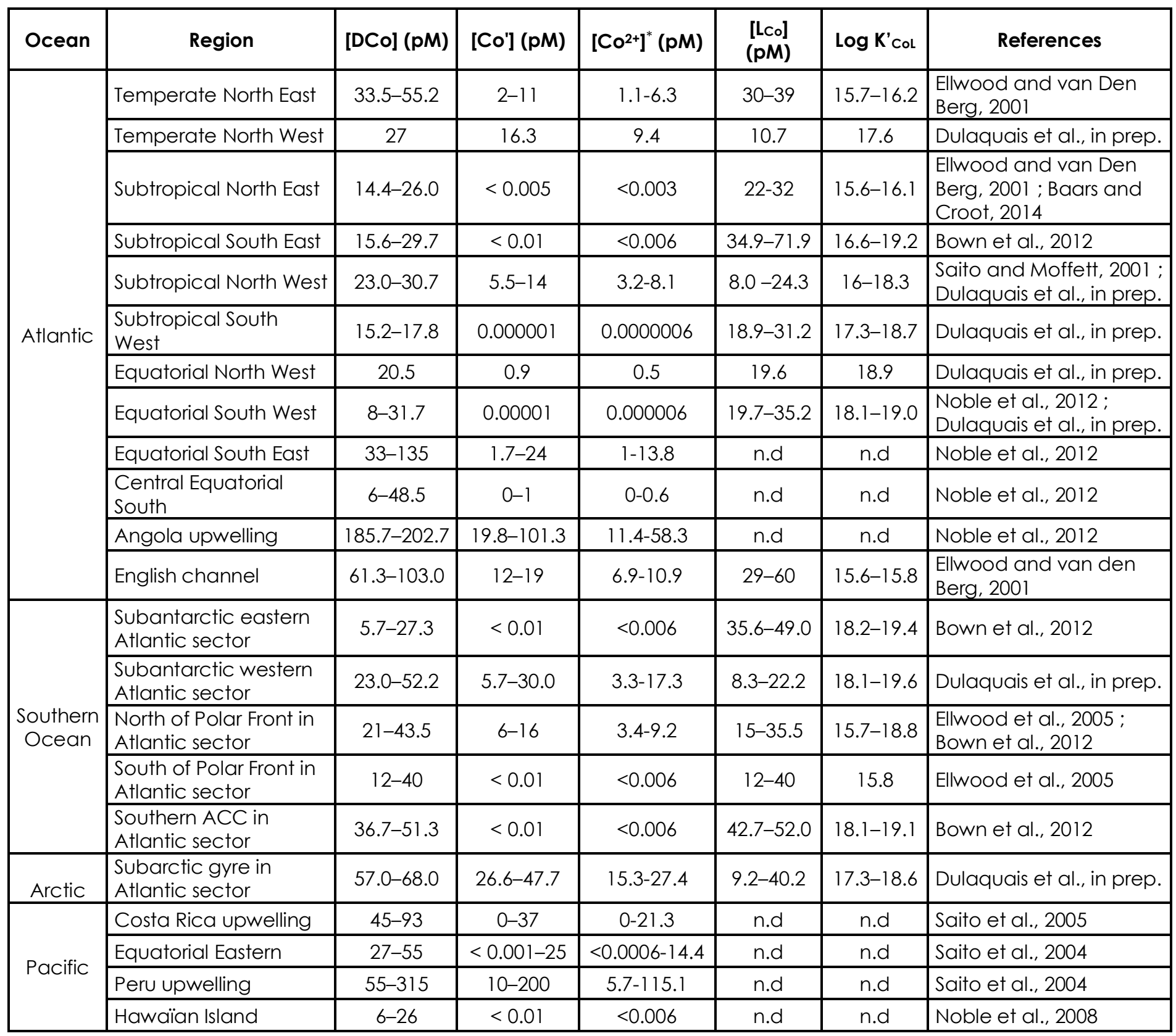

${ }^{*}\left[\mathrm{CO}^{2+}\right]$ is calculated by dividing [Co'] by the inorganic side reaction coefficient of cobalt at pH 8.2 (log $\alpha \mathrm{Co}^{\prime}=0.24$; Turner et al., 1981) 
Table 4. Organic speciation of zinc in the worldwide surface ocean: concentrations of dissolved zinc (DZn), inorganic zinc (Zn'), free zinc ions $\left(Z n^{2+}\right)$, organic zinc-binding ligand (Lzn), and conditional stability constant of ZnL complexes (K'ZnL).

\begin{tabular}{|c|c|c|c|c|c|c|c|}
\hline Ocean & Region & [DZn] (nM) & [Zn'] (pM) & {$\left[\mathrm{Zn}^{2+}\right]^{*}(\mathrm{pM})$} & $\begin{array}{l}{\left[\mathrm{Lzn}_{\mathrm{z}}\right]} \\
(\mathrm{nM})\end{array}$ & $\log K^{\prime} z n L$ & References \\
\hline \multirow{4}{*}{ Atlantic } & Temperate North East & $0.3-0.6$ & $10-25$ & $4.6-11.4$ & $1.3-2.3$ & $10.2-10.4$ & Ellwood \& van Den Berg 2000 \\
\hline & $\begin{array}{l}\text { Subtropical North } \\
\text { East }\end{array}$ & $0.3-0.5$ & $6.5-6.8$ & $3.0-3.1$ & $2.4-2.5$ & $10.3-10.6$ & Ellwood \& van Den Berg 2000 \\
\hline & Sargasso Sea & $0.2-0.4$ & $6-10$ & $2.7-4.6$ & $0.6-1.2$ & $9.8-10.5$ & Jakuba et al., 2008b \\
\hline & English Channel & $0.6-1.5$ & $151-205$ & 69.0-93.7 & $0.4-1.4$ & 10.2 & Ellwood \& van Den Berg 2000 \\
\hline \multirow{8}{*}{ Pacific } & $\begin{array}{l}\text { Western North Pacific } \\
\text { gyre }\end{array}$ & $0.24-0.43$ & $17-108$ & $7.8-49.4$ & $0.7-1.2$ & $9.6-10.2$ & Kim et al., $2015 a$ \\
\hline & Sea of Japan & 0.88 & 257 & 117.5 & 1.3 & 9.1 & Kim et al., $2015 a$ \\
\hline & Sea of Okhotsk & 2.11 & 234 & 107 & 2.6 & 9.5 & Kim et al., $2015 a$ \\
\hline & Temperate North East & 0.1 & 5 & 2.3 & 1.1 & 10 & Jakuba et al., 2012 \\
\hline & Temperate North & $0.2-0.9$ & $2-7$ & $0.9-3.2$ & $1.1-1.4$ & 10.5 & $\begin{array}{l}\text { Jakuba et al., } 2012 \text {; Lohan et } \\
\text { al., } 2005 \text {; Donat and Bruland, } \\
1990\end{array}$ \\
\hline & $\begin{array}{l}\text { Temperate North } \\
\text { West } \\
\end{array}$ & 0.78 & 33 & 15.1 & 1.4 & 9.8 & Jakuba et al., 2012 \\
\hline & $\begin{array}{l}\text { Subtropical North } \\
\text { West }\end{array}$ & $0.07-0.18$ & $20-54$ & $9.1-24.7$ & $0.2-0.3$ & $9.1-9.7$ & Kim et al., $2015 a$ \\
\hline & $\begin{array}{l}\text { Subtropical North } \\
\text { East } \\
\end{array}$ & $0.15-0.3$ & $2-8$ & $0.9-3.7$ & $1-1.4$ & $10.7-10.9$ & Bruland, 1989 \\
\hline \multirow{2}{*}{$\begin{array}{l}\text { Southern } \\
\text { Ocean }\end{array}$} & $\begin{array}{l}\text { Subantarctic in the } \\
\text { Pacific sector }\end{array}$ & $0.01-0.03$ & $0.3-1.1$ & $0.1-0.5$ & $1.2-2.4$ & $10.0-10.8$ & Ellwood, 2004 \\
\hline & Atlantic sector & $0.8-3.5$ & $97-2800$ & 44.3-1279.8 & \begin{tabular}{|l|}
$1.4-5.3$ \\
\end{tabular} & $9.1-10.4$ & Baars \& Croot, 2011 \\
\hline Arctic & Bering Sea & 0.89 & 71 & 32.4 & 3.6 & 9.3 & Jakuba et al., 2012 \\
\hline $\begin{array}{l}\text { Indian } \\
\text { Ocean }\end{array}$ & North & 0.26 & 47 & 21.5 & 0.5 & 10 & Kim et al., 2015b \\
\hline Black Sea & West & $1.2-5.5$ & $29.0-110.0$ & $13.2-50.3$ & $6.3-7.5$ & $9.4-10.3$ & Muller et al., 2001 \\
\hline
\end{tabular}

${ }^{*}\left[\mathrm{Zn}^{2+}\right]$ is calculated by dividing [Zn'] by the inorganic side reaction coefficient of zinc at $\mathrm{pH} 8.2\left(\log \alpha \mathrm{Co}^{\prime}=\right.$ 0.34 ; Turner et al., 1981) 


\section{FIGURE CAPTIONS}

Figure 1. Growth rates $(\mu$; in day-1) of $E$. huxleyi as a function of logarithmic values of $\left[\mathrm{CO}^{2+}\right],\left[\mathrm{Zn}^{2+}\right]$ and $\left[\mathrm{Cd}^{2+}\right]$ present in $\mathrm{f} / 50$ Aquil growth media. The replete metal conditions are as following: $\left[\mathrm{Co}^{2+}\right]=15 \mathrm{pM} ;\left[\mathrm{Zn}^{2+}\right]=20 \mathrm{pM}$; $\left[\mathrm{Cd}^{2+}\right]=13 \mathrm{pM}$.

Figure 2. Cellular organic carbon content POC (a), organic carbon production rate (b), cellular nitrogen PON (c), and nitrogen cellular to organic carbon ratio PON/POC (d) of $E$. huxleyi as a function of logarithmic values of [CO $\left.{ }^{2+}\right]$ and $\left[\mathrm{Zn}^{2+}\right]$.

Figure 3. Cellular inorganic carbon content PIC (a), inorganic carbon production per cell (b), and inorganic to organic carbon ratio PIC/POC (c) of E. huxleyi as a function of logarithmic values of $\left[\mathrm{CO}^{2+}\right]$ and $\left[\mathrm{Zn}^{2+}\right]$.

Figure 4. Scanning electron microscope pictures of E. huxleyi grown in replete (left) and limiting (right) $\mathrm{Zn}^{2+-} \mathrm{CO}^{2+}$ conditions. 
Figure 1

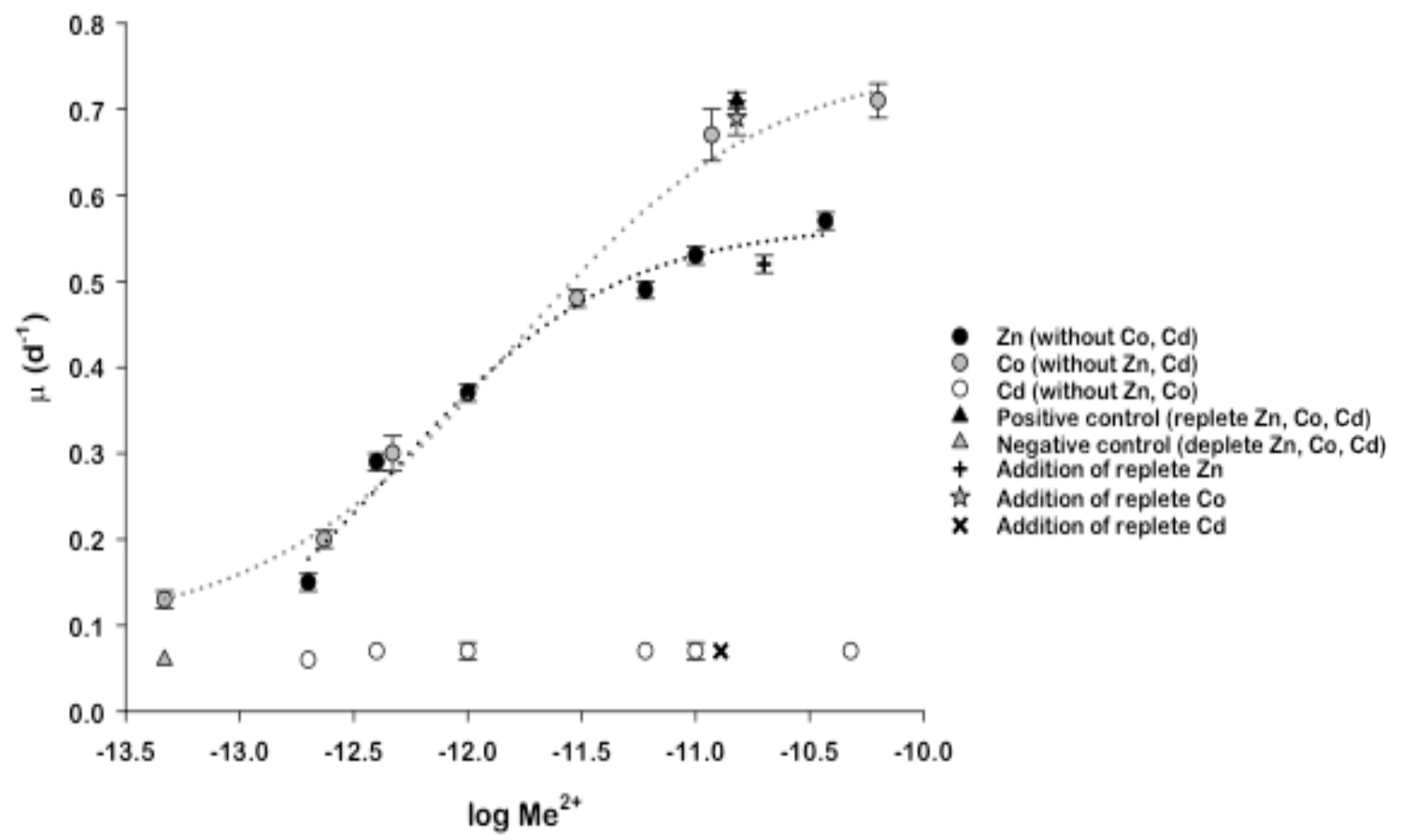


Figure 2
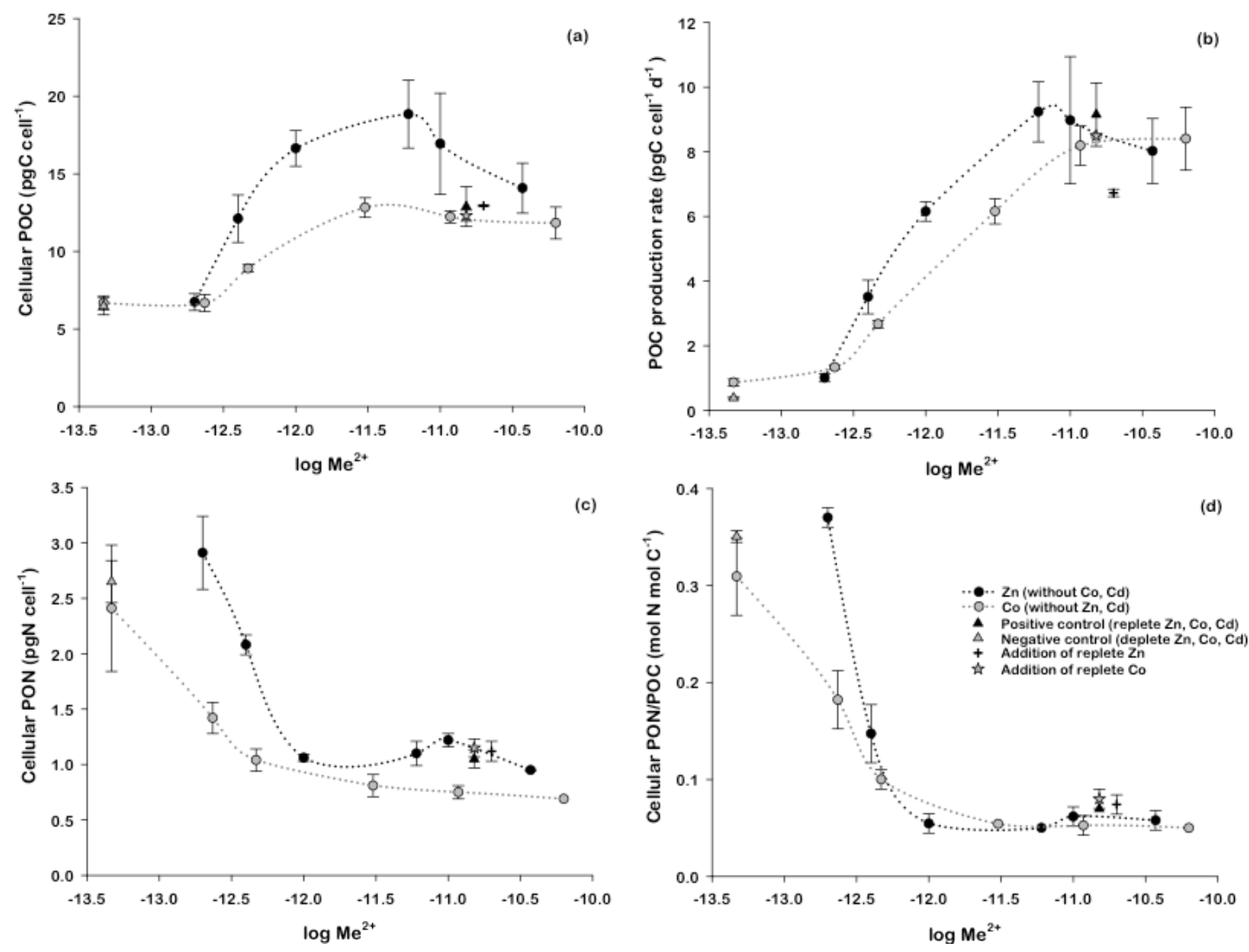
Figure 3
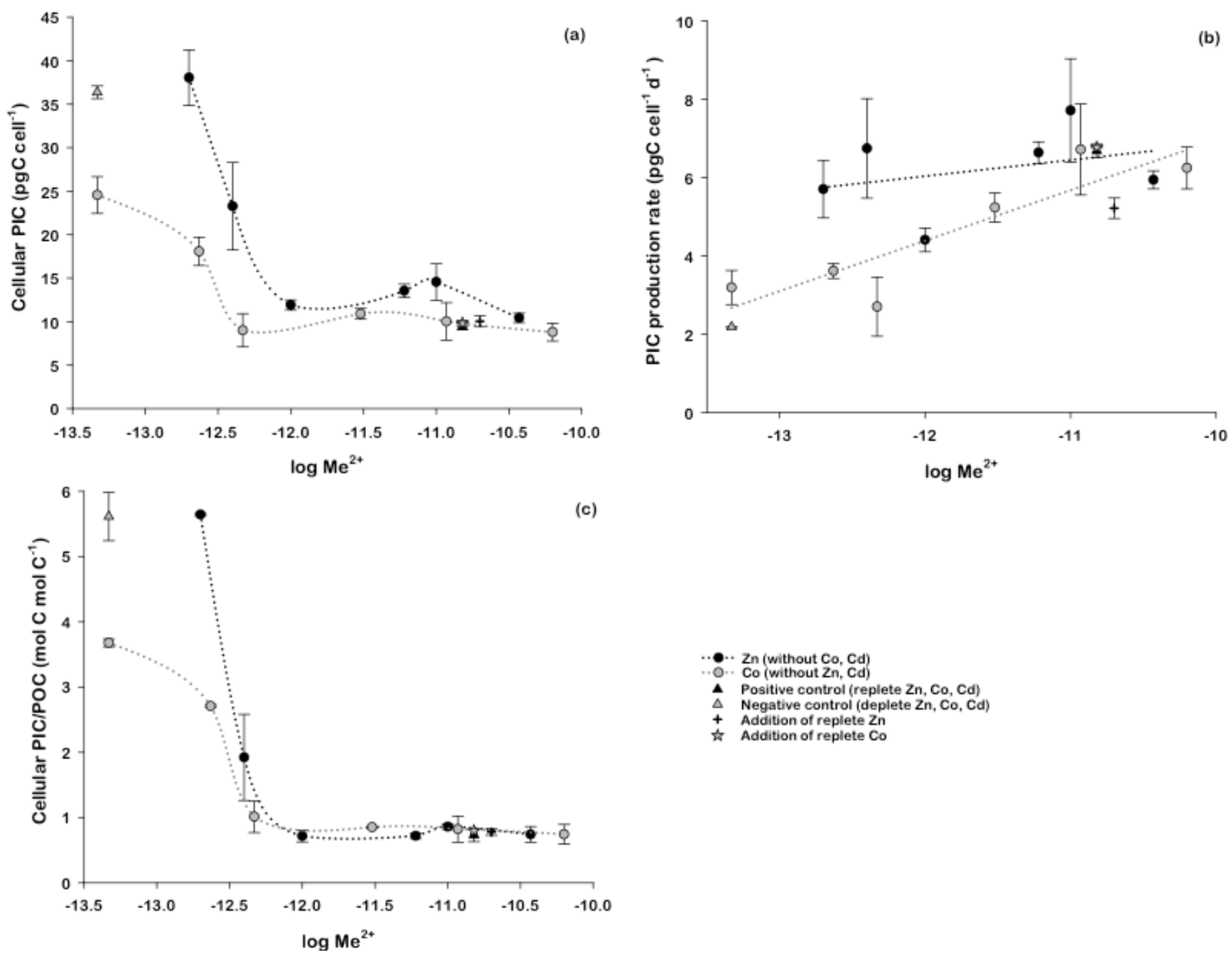

-.. Zn (without Co, Cd)

Positive control (replete $\mathrm{Zn}, \mathrm{Co}, \mathrm{Cd}$ )

Negative control (deplete $\mathrm{Zn}, \mathrm{Co}, \mathrm{Cd}$

Addition of replete Z

Addition of replete $\mathrm{Zn}$

b) 
Figure 4
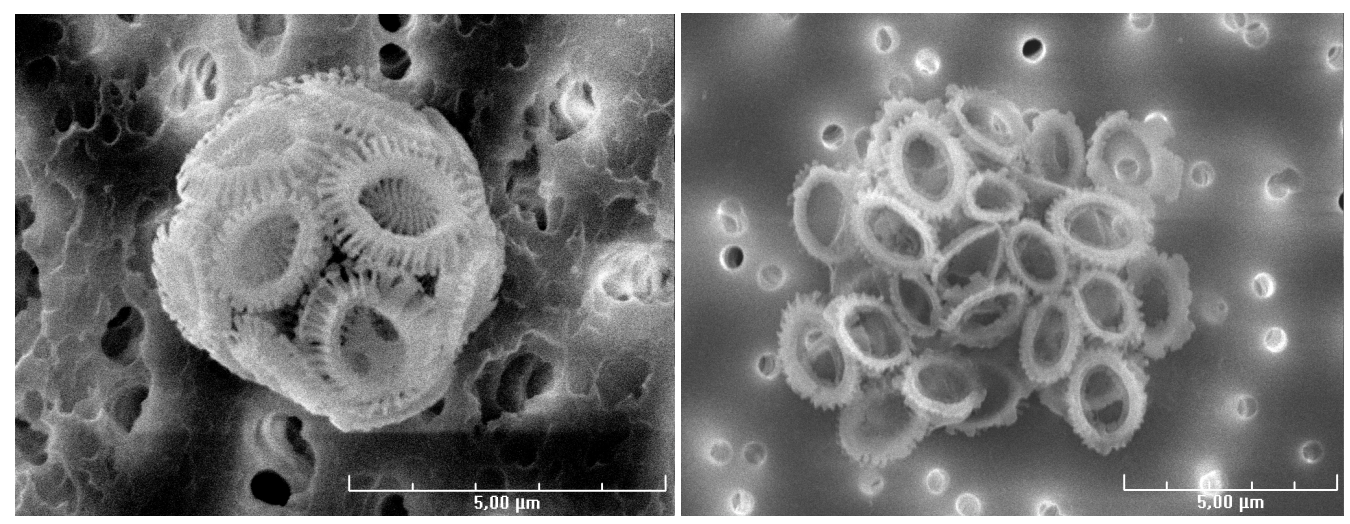